|Araştırma Makalesi / Research Article|

\title{
Osmanlı Devleti’nde Eğitimin Modernleşmesi Sürecinde Öncü Bir Şahsiyet: Ahmed Kemal Paşa'nın Eğitim Politika ve Uygulamaları (1847-1878) ${ }^{1}$
}

\section{A Pioneering Character in the Process of Educational Modernization in the Ottoman Empire: Ahmed Kemal Pasha's Educational Policies and Practices (1847-1878)}

\section{Eyüp CÜCÜK², Ayhan DOĞAN³}

\author{
Anahtar Kelimeler \\ Eğitim Tarihi, \\ Eğitim Politikaları, \\ Osmanlı Modernleşmesi, \\ Ahmed Kemal Paşa, \\ Maarif-i Umumiye \\ Nezareti,
}

\section{Keywords \\ History of Education, \\ Educational Policies, \\ Ottoman \\ Modernization, \\ Ahmed Kemal Pasha, \\ The Ministry of \\ Education,}

Başvuru Tarihi/Received

27.08.2020

Kabul Tarihi /Accepted

15.11.2020
Öz

Osmanlı Devleti'nde eğitimin modernleşmesi sürecinde kritik rol oynamış figürlerin çok yönlü biyografileri ortaya konulmadan ve yaşadıkları dönemin eğitim politika ve uygulamalarına katkısı kapsamlı ve özgün bir yaklaşımla analiz edilmeden Tanzimat Dönemi eğitim modernleşmesini anlamak ve bu bağlamdaki çıktıları gelişimsel ve bütüncül bir bakışla değerlendirmek mümkün görülmemektedir. Bu araştırmanın amacı, Osmanlı Devletinde eğitimin modernleşmesi sürecinde öncü bir şahsiyet olan Ahmed Kemal Paşa'nın farklı tarihlerde sürdürdüğü üst düzey eğitim yöneticiliği görevlerinde ortaya koymuş olduğu eğitim politika ve uygulamalarının incelenmesidir. Nitel yaklaşımın kullanıldığı bu araştırma, özgün ve birincil kaynaklara dayalı bir tarih araştırması olarak tasarlanmıştır. Araştırma verileri, doküman incelemesi yöntemiyle toplanmış olup Kemal Paşa'nın mühür ve imzasını taşıyan çok sayıdaki arşiv belgesi başta olmak üzere veri çeşitliliğini sağlamak için farklı türden veri kaynakları da kullanılmıştır. İçerik analizi yöntemiyle çözümlenen verilerden hareketle Kemal Paşa'nın, yaşadığı dönemin eğitim hayatına etkisi tespit edilmeye çalışıımışır. Sonuç olarak Kemal Paşa'nın, Tanzimat Döneminin reformist ve aydın bürokratlarından biri olarak özellikle Osmanlı eğitim modernleșmesi sürecinde yön tayin edici, belirleyici ve öncü bir hizmette bulunmuş bir eğitimci olduğu anlaşılmıştır. Bu süreçte çok yönlü eğitim politikalarının geliştirilmesine ve uygulanmasına hem teorisyen hem pratisyen rolleriyle katkı sunan Ahmed Kemal Paşa'nın yenilikçi, pragmatist özelliklere sahip bir eylem adamı olduğu söylenebilir.

\section{Abstract}

It is not possible to appreciate the educational modernization during the Tanzimat Period and to evaluate the outcomes of this process with a developmental and holistic perspective without presenting the detailed biographies of the figures having critical roles during the modernization of education in the Ottoman Empire and analysing their contribution to the educational policies and practices of their period with a comprehensive and original approach. The present study aimed to examine the educational policies and practices adopted by Ahmed Kemal Pasha, as a pioneering character during the process of educational modernization in the Ottoman Empire, in his senior educational administration positions on several occasions. The present study was designed as historical research based on original and primary sources by exploiting a qualitative method. The research data were collected through a document analysis method by referring to different types of data sources especially a great number of archive documents with the seal and signature of Kemal Pasha, which guaranteed data diversity. The effect of Kemal Pasha on the educational life of his period was attempted to be revealed through the findings based on the content analysis method. As a result of the study, it was concluded that Kemal Pasha, as one of the reformists and intellectual bureaucrats of the Tanzimat Period, was a man of education who played a directional, decisive, and pioneering role especially during the process of Ottoman educational modernization. Accordingly, Ahmed Kemal Pasha, an innovative and pragmatist activist, contributed to the development and implementation of sophisticated educational policies during the Tanzimat Era, with both his doctrinaire and practitioner functions.

${ }^{1}$ Bu çalışma, Gaziantep Üniversitesi Bilimsel Araştırma Projeleri Birimi desteğiyle yürütülerek Gaziantep Üniversitesi Sosyal Bilimler Enstitüsü Tarih Ana Bilim Dalında Eyüp CÜCÜK'ün, Doç. Dr. Ayhan DOĞAN danışmanlığında tamamlamış olduğu doktora tezinden üretilmiştir.

${ }^{2}$ Sorumlu Yazar, Gaziantep Üniversitesi, Gaziantep Eğitim Fakültesi, Eğitim Bilimleri Bölümü, Gaziantep, Türkiye; https://orcid.org/0000-00032660-8009

${ }^{3}$ Gaziantep Üniversitesi, Gaziantep Eğitim Fakültesi, Eğitim Bilimleri Bölümü, Gaziantep, Türkiye; https://orcid.org/0000-0002-3835-0124

Alıntı/Citation: Cücük, E., \& Doğan, A. (2020). A Pioneering Character in the Process of Educational Modernization in the Ottoman Empire: Ahmed Kemal Pasha's Educational Policies and Practices (1847-1878). Kastamonu Education Journal, 28(6), 2465-2483. doi:10.24106/kefdergi.786703 


\section{Introduction}

It does not seem possible to appreciate the educational modernization during the Tanzimat Period and to evaluate the outcomes of this process with a developmental and holistic perspective without presenting the detailed biographies of the figures having critical roles during the modernization of education in the Ottoman Empire and analysing their contribution to the educational policies and practices of their period with a comprehensive and original approach. Ahmed Kemal Pasha, who lived between 1808/1809-1887, was one of the most prominent figures of the Ottoman modernization process. In addition to great many bureaucratic and diplomatic roles in different areas, the period in which he held senior positions during the Tanzimat education spanned approximately 30 years between $1847-1876$. In this process, he took the opportunity to direct the educational reform initiatives by assuming senior positions of both the legislation and the execution. The present study aimed to examine the educational policies and practices adopted by Ahmed Kemal Pasha, as a pioneering character during the process of educational modernization in the Ottoman Empire, during his senior educational administration positions on several occasions.

\section{Method}

The present study was designed as historical research based on original and primary sources through exploiting a qualitative method. The research data were collected through a document analysis method by referring to different types of data sources especially a great number of archive documents with the seal and signature of Kemal Pasha, which guaranteed data diversity. The effect of Kemal Pasha on the educational life of his period was attempted to be revealed through the findings based on the content analysis method.

\section{Result and Discussion}

As a result of the findings of the present study investigating the educational policies and practices of Ahmed Kemal Pasha, one of the leading actors of the Ottoman educational modernization process between 1847-1876, some interpretations and inferences were made based on a number of original documents and works and it was observed that he had a leading role in the modernization of Ottoman education. His educational administration posts since 1847, which included the Deputy Director of Public Schools, Minister of Public Education, Head of Department of Education in the Council of State, and the Minister of Education six times on different dates, were significant in the context of the modernization of Ottoman education during the Tanzimat period. It can be emphasized that Kemal Pasha, as one of the reformists and intellectual bureaucrats of the Tanzimat Period, was a man of education who played a directional, decisive, and pioneering role especially during the process of Ottoman educational modernization. It can be alleged that Kemal Pasha, who was concluded to be one of the protagonists of this process with his doctrinaire and practitioner (more prominently) roles, served the modernization of Ottoman education for many years and spent a lifetime for this cause.

When Kemal Pasha held the positions of the Deputy Director of Public Schools and Minister of Public Education between the years of 1847-1854, remarkable activities were carried out for the establishment and dissemination of secondary schools both in the capital city and in the provinces. The more sophisticated extensions of the policies and practices of this period can be observed during Kemal Efendi's ministry beginning in the 1860s. Secondary schools, which were initiated to be "a public education movement", can be argued to provide a significant basis for the cultivation of individuals with modern identity to be inherited to the Republic of Turkey from the Ottomans, the centralization of the Ottoman Empire, and the dissemination of values from the centre to the periphery.

Kemal Pasha's observations and examinations on site of the European school system in the 1850s and 1860s were highly important in terms of bringing a modern perspective to Ottoman educational reforms. Accordingly, Kemal Efendi not only pioneered the first practices for the introduction of modernity into Ottoman education but also worked for the transformation of these educational reforms into permanent policies by putting them in a certain order in the senior educational administration positions, he was subsequently appointed to. Therefore, the effect of Ahmed Kemal Pasha's examinations regarding the European educational system on the Ottoman education system continued to be a historical phenomenon in the following periods.

It was observed that many different types of schools such as language schools, vocational schools, industrial school, medical school, etc. were opened especially in 1866-1867 during Ahmed Kemal Pasha's educational administration period in addition to regular ones such as primary, secondary and high schools. The number of individuals trained in those schools had been increased through the dissemination of modern schools in the period between the declaration of the Tanzimat Edict (1839) until 1867. The quantitative boost resulted in qualitative development. As a natural consequence, efforts to open higher schools, technical and vocational schools other than basic education, and to expand their spheres of influence had been accelerated. It was undoubtedly the result of Ahmed Kemal Pasha's policy of increasing the number and the graduates of modern secondary schools. Moreover, it was highly expectable to set an example for later periods through the efforts and experiences to spread the "element of education" with a gradual centralized structure across the country. Thus, it can be regarded to be the basis for the policies of the dissemination of education, the creation of an Ottoman society compatible with the state ideology, and the provision of social discipline and control of the society which gained rapid momentum in the period of Sultan Abdulhamid II. 


\section{GiRiş}

19. yüzyılın uluslararası arenası aklı esas alan modernite paradigmasının kurumsallaşarak yerleşik hale gelmesine, Bonapartist yönetim biçiminin (merkezî bir devleti savunan asker ve bürokratların izlediği politikalar bütünü) güçlenmesine, monarşik yönetim düşüncesinin zayıflamasıyla birlikte devlet-vatandaş ilişkisinin farklılaşmasına ve farklı misyonlar yüklenen eğitimin kitlesel hale gelmesine sahne olmuştur. Osmanlı Devleti'nde ise 18. yüzyılın başlarından itibaren görülmeye başlanan Osmanlı yenilik hareketleri, Sultan III. Selim Dönemi'nde (1789-1807) Nizam-ı Cedit adı verilen "yeni düzen" ile birlikte oldukça belirginleşmiştir. III. Selim'in ardından gelen Sultan II. Mahmud Dönemi'nde (1808-1839) gerçekleştirilen köklü ıslahatlarla sürdürülen yenilik hareketleri, Sultan Abdülmecid'in tahta çıkışının akabinde 3 Kasım 1839 tarihinde ilan edilen Tanzimat Fermanı ile birlikte modernleşme ekseninde yeniden yapılandırılarak zirveye ulaşmıştır. Tanzimat'ın ilanıyla birlikte oluşturulan "ikinci yeni düzen" Osmanlı eğitim modernleşmesini anlamlandırabilmek için önemli bir bağlam sunar. Bu süreçteki eğitim modernleşmesi girişimlerinde Fransa'yı model alan Osmanlı aydın ve bürokratları, Fransız politika ve uygulamalarını bağlamsal koşullar ve kültürel kodlar doğrultusunda uyarlamak için büyük bir çaba sarf etmiştir. Bu noktada söz konusu yeni düzenin temel dayanaklarını oluşturan kişiler, kurumlar ve resmi düzenlemeler ile bunlar arasındaki ilişkiyi hesaba katmak oldukça önem arz etmektedir.

Bilindiği üzere Mustafa Reşid Paşa tarafından hazırlanan Tanzimat Fermanı, Osmanlı modernleşmesinin en temel yasası olarak yeni bir dönemin kapısını açmıştır. Ferman'da ülkenin maarif hayatına ilişkin herhangi bir ibare bulunmamasına (İnalcık ve Seyitdanlıŏlu, 2017, s. 12-16) rağmen genel anlamda modernleşmenin esasları ve ana hatlarını tayin eden bir karaktere sahip olması bakımından bu Ferman'ın eğitim alanında daha sonra gerçekleştirilecek reformlara arka plan oluşturduğu ileri sürülebilir. Tanzimat Fermanı'nın ardından yeni düzenin esasları çerçevesinde belirlenen maarif alanındaki reformlara ilişkin ilk politika belgeleri, Tanzimat Dönemi Osmanlı maarifinin şekillendirilmesinde temel unsur olmuştur. Pek çok değişkenin yanı sıra başat faktör olarak Tanzimat Dönemi genel maarif hayatının ana hatlarını düzenlediği ve daha sonra geliştirilen politikalara temel oluşturduğu düşünülen söz konusu ilk politika belgeleri şunlardır: II. Mahmud’un 1824 tarihli Fermanı (Mahmud Cevad, 2002, s. 12), Meclis-i Umûr-ı Nâfıa'nın Şubat 1839 yılında yayımladığı layiha (Mahmud Cevad, 2002, s. 5-17), 17 Mart 1839 tarihli Esad Efendi'nin layihası (Mahmud Cevad, 2002, s. 16-17), 3 Kasım 1839 tarihli Tanzimat Fermanı (Inalcık ve Seyitdanlıŏlu, 2017, s. 1216), Tanzimat'ın ilanıyla başlayan yeni dönemle birlikte Sultan Abdülmecid'in 1845 tarihli fermanı (Hatt-ı Hümayunu) (Engelhardt, 2017, s. 83), bu dönemde kurulan Meclis-i Maarif-i Muvakkatin eğitim reformuna ilişkin oluşturduğu raporlar (Maarif Salnamesi, H. 1321/M. 1903-1904, s. 18-19; Cevdet Paşa, 1991, s. 37-38; Mahmud Cevad, 2002, s. 21 ). Öne sürülen bu belgeler Tanzimat maarifini şekillendirmekle birlikte daha sonraki süreçte izlenen politikalara da öncülük etmiştir. Bu bağlamda 1856'da yayımlanan ve eğitim alanında önemli düzenlemeler içeren Islahat Fermanı (İnalcık ve Seyitdanlıoğlu, 2017, s. 17-25) ile 1869 yılında yayımlanan ve Osmanlı eğitim modernleşmesini zirveye ulaştıran Maarif-i Umumiye Nizamnamesi (T.C. Cumhurbaşkanlığı Devlet Arşivleri Başkanlığı Osmanlı Arşivleri (BOA), İ. MMS. 37/1541; BOA. ŞD. Defter no: 234; Düstur H.1289/M. 1872-1873, s. 184-219; Bilim, 2002, s. 437-474) bahsi geçen ilk politika belgelerinin bir sonucu olarak tezahür etmiştir.

Maarif modernleşmesi sürecinde etki değeri taşıyan bu belgeler arasında özellikle Tanzimat'ın ilanından sonra yayımlanan belgelerin eğitim politikalarının belirlenmesi, eğitimin kurumsallaşması ve belirli bir sistem dahilinde inkişafı bakımından daha kapsayıcı bir etkiye sahip olduğu düşünülmektedir. Bu kapsamda ele alınacak olursa Osmanlı özelinde yeni bir düzene işaret eden reform hareketleri kapsamında maarif alanında bir yenilik hamlesine girişmek için 1845 yılını beklemek gerekmiştir. Sultan Abdülmecid'in Babıali'ye her yılbaşında gerçekleştirdiği rutin bir uygulama haline dönüşen ziyaretleri (Akyıldız, 2012, s. 66) kapsamındaki 13 Ocak 1845 tarihli ziyaretinde, Tanzimat maarifinin belki de bu açıklıktaki ilk politika metni sayılabilecek olan fermanı yayımlanmıştır. Her ne kadar Engelhardt bu fermanın, bizzat Sultan'ın kendisi tarafından hazırlandığını ve Babıali'deki söz konusu ziyarette okunduğunu ifade etse de (Engelhardt, 2017, s. 83) Tanzimat'ın mucidi Mustafa Reşit Paşa'nın bu reform girişiminde önemli bir payı olması kuvvetle muhtemeldir. Sultan bu fermanında, Tanzimat reformlarıyla ilerleme gösterilmesine yönelik düşünce ve emellerinin uygulamaya geçirilmesi noktasında gerekli çabanın gösterilmediğini, beklenen neticelere ulaşılamadığını ifade etmiştir. Askeri alanda bazı ıslahatlara girişilmiş olsa da bunların, ülkenin kalkınması için gerekli olan sağlam ve güçlü bir arka plana sahip olmadığını belirtmiştir. Mevcut durumdan duyduğu rahatsızlığı ve üzüntüsünü kattığı ifadelerinde, orada bulunan devlet adamlarını sert bir dille eleştirerek başta Sadrazam olmak üzere kabine üyelerine gerekli tedbirlerin bir an önce alınmasını emretmiştir. Bu çerçevede reformların başarıya ulaşması suretiyle ülkenin gelişmesi ve tebaanın mutluluğunun sağlanabilmesinin hem dinî hem dünyevî işlerde cehaletin ortadan kaldırılmasıyla mümkün olabileceğinin altını çizmiştir. Sonuç olarak bilim, fen ve sanayi alanlarında öğretimin yapıldığı yeni mektepler açılmasını öncelikli konu olarak gördüğünübelirtmiştir.

Sultan'ın emir ve uyarıları doğrultusunda çok geçmeden faaliyete başlanmıştır. Meclis-i Valada ele alınan bu konu hakkında, eğitim alanında çalışmalar yürütmek üzere Meclis-i Maarif-i Muvakkat adlı geçici bir komisyon kurulmasına karar verilmiştir (Maarif Salnamesi, H. 1321, s. 18-19; Mahmud Cevad, 2002, s. 19-21). 12 Nisan 1845 tarihindeki kuruluşunun ardından çalışmalara başlayan bu geçici maarif meclisi Tanzimat Dönemi maarif politikalarını tayin eden oldukça önemli üç layiha hazırlamıştır. Bu layihalardan ilki sıbyan mekteplerinde gerçekleştirilmesi gereken ıslahatı, ikincisi orta kademede yeni mektepler açılmasını, üçüncüsü ise kurulması planlanan Darülfünun adlı bir yükseköğretim kurumuna ilişkin düzenlemeyi kapsamaktadır (Maarif Salnamesi, H. 1321, s. 18,-19; Cevdet Paşa, 1991, s. 37-38; Mahmud Cevad, 2002, s. 21). Ayrıca meclisin öngördüğü eğitim reformunda, ülkedeki maarife yönelik politika ve uygulamaların belirli bir düzen içerisinde oluşturulması ve yürütülmesini sağlayacak bir kurum olarak daimi surette bir Maarif Meclisi kurulması gerektiğinin altı çizilmiştir. Bunun üzerine Meclis-i Vala-yı Ahkam-ı Adliyenin 21 Temmuz 1846 tarihli kararıyla daimî surette bir Meclis-i Maarif kurulmuştur (Erdoğdu, 1995, s. 26-27; Ergin, 1977, s. 440-441). 
Tanzimat Dönemi eğitim modernleşmesi bağlamında buraya kadar ifade edilen yeni kurumları oluşturan ve resmi düzenlemeleri (politika belgelerini) hazırlayan kişiler devrin padişahı Sultan Abdülmecid başta olmak üzere Babıali'de belirli makamlarda bulunarak güç ve nüfuz sahibi bulunan Mustafa Reşid, Âli ve Fuad Paşa gibi "maruf simalar"dır (Türkgeldi, 2013). Söz konusu karakterler politika oluşturan aktörler olarak Tanzimat Dönemi genel maarif politikalarını belirleyen ana unsurlardır. Osmanlı eğitim modernleşmesini söz konusu ana etmenler çerçevesinde mütalaa ederek daha sonra gerçekleştirilen eğitim reformlarını böylesi bir zeminde etüt etmek gerekir. Buradan hareketle bu araştırmanın konusu olan Ahmed Kemal Paşa'nın Tanzimat Dönemi'ndeki Mekatib-i Umumiye Muavinliği/Nazırlığı, Şura-yı Devlet Maarif Dairesi Başkanlığı ve (altı kez atandığı) Maarif Nazırlığı gibi görevlerini de bu kapsamda ele almak Kemal Paşa'nın maarif modernleşmesindeki rolünün anlaşılmasına yardımcı olacaktır. Bu noktada Meclis-i Maarif-i Umumiyenin bir kararıyla, maarif alanındaki reformların uygulayıcısı rolünü üstlenmek üzere 1847 yılında kurulmuş olan Mekatib-i Umumiye Nezareti bünyesinde gerçekleştirilen faaliyetlerin bu genel politika ve politika üretici şahsiyetler çerçevesinde değerlendirilmesi gerekir.

Bu araştırma kapsamında Tanzimat Dönemi Osmanlı eğitim politika ve uygulamalarına katkısı incelenen Ahmed Kemal Paşa, 1808/1809 (H. 1223) yılında İstanbul'da dünyaya gelmiştir (Maarif Salnamesi, H. 1316/M. 1898-1899, s. 34). Sultan kethüdalarından olan babası, El-hac Seyid İbrahim Ağa olarak bilinmektedir (İnal, 1969, s. 1150). Özel hocalardan ilim tahsil etmek suretiyle ilköğrenimini tamamlamıştır. Memuriyet hayatına 1825/1826 yılında Bab-ı Defteri Mektupçu Kaleminde başlamıştır. 1831'de Ceride Nezareti Bab-ı Defteri Başkâtipliği, 1835-36 yılları arası Osmanlı-İran (Tahran) Elçiliği Sır Katipliği ve Tercümanlığı görevlerini yerine getirdikten sonra 1837 yılında Sadaret Mektupçu Kalemi Memurluğuna atanmıştır. Bu görev, Kemal Efendi'nin esas memuriyet alanı olarak uzun yıllar uhdesinde kalmıştır. Bu görevine ilaveten 1837-39 yılları arası Osmanlı Devleti-i̇ran (Tahran) Elçiliği, 1839'da Takvim-i Vekayi Farsça Mütercimliği görevlerine getirilmiştir. Mütercimlik görevi de uzun yıllar uhdesinde kalan bir görev olmuştur. 1841'de Mısır'a, 1843-45 yılları arasında Musul ve Cizre bölgesine özel memuriyetle görevlendirilmiştir. Maarif alanındaki ilk görevi ise Mekatib-i Umumiye Nezaretinin kuruluşu ile birlikte 3 Ocak 1847 tarihinde atandığı Nazır Muavinliği olmuştur. 26 Aralık 1847 tarihinde ise Mekatib-i Umumiye Nazırlığına atanmış olup bu görevi Mayıs 1854 tarihine kadar sürdürmüştür. Nazır unvanını taşıdığı yıllarda, eğitim alanındaki yeni gelişmeleri takip etmek amacıyla Avrupa'nın çeşitli ülkelerine görevlendirmiş olup modern Osmanlı maarifinin terakkisi için pek çok reform uygulamasına imza atmıştır. Osmanlı bilimler akademisi niteliğindeki Encümen-i Danişe ve Fransız bilimler akademisi Société Asiatique'e üye olarak seçilmiştir. 1854-57 yılları arasında ise Osmanlı Devleti-Berlin Ortaelçiliği görevini sürdürmüştür. Bunun akabinde 1857-59 yılları arasında Bosna-Hersek bölgesine müfettiş olarak görevlendirilmiştir. Dönüşünde Şehzadelerin Ders Nazırlığı, Meclis-i Ali Tanzimat Üyeliği ve Harem-i Hümayun Masarifat Nazırlığına getirilmiştir. 24 Kasım 1861-18 Kasım 1862 tarihleri arasında Maarif-i Umumiye Nazırlığına ilk kez atanmıştır. 18 Kasım 1862-24 Nisan 1865 tarihleri arasında Meclis-i Vala-yı Ahkam-ı Adliye Üyeliği ve 24 Nisan 1865-24 Ağustos 1867 tarihleri arasında ikinci kez Maarif Nazırlığı görevini sürdürmüştür. Maarif Nazırıyken kısa bir süreliğine Belçika'ya görevlendirilmiş, dönükten sonra Evkaf-ı Hümayun Nazırlığını vekâleten yürütmüştür. 1867'de Meclis-i Vala-yı Ahkam-ı Adliyeye ikinci kez üye olarak atanmıştır. 5 Mart 1868'de Şura-yı Devlet Üyeliğine ilk kez tayin edilerek burada Maarif Dairesi Başkanlığını yürütmüştür. Bu görevdeyken en önemli icraatı, eğitim komisyonu başkanı olarak Maarif-i Umumiye Nizamnamesi'nin hazırlanması olmuştur. 9 Ağustos 1870'te, İran Şahı'na mihmandar olarak Vezirlik (Paşa) rütbesiyle Bağdat'a görevlendirilmiştir. 1870-78 yılları arasında iki kez Evkaf Nazırlığına, dört kez Maarif Nazırlığına, iki kez Şura-yı Devlet Üyeliğine tayin edilmiştir. 11 Ocak 1878'de Meclis-i Ayan Üyeliği ve 9 Haziran 1878'de Sultan Abdülaziz'in Hanedan Hizmeti Nazırlığına atanmıştır. Bu son nazırlık görevi 1887 yılında vuku bulan vefatına değin uhdesinde kalmıştır (Maarif Salnamesi, H. 1316, s. 34; İnal, 1969, s. 1150-1159; Davud, 2017, s. 421-422).

Görüldüğü üzere yaşamı boyunca maliye, idare, yönetim, eğitim, hukuk, denetim, diplomasi gibi çok çeşitli alanlardaki devlet hizmetinde görev yapmıştır. Bu hizmetlerinin karşılığı olarak çok sayıda ödül ve nişana layık görülmüştür. Yaşadığı dönemde, "büyük âlim ve edip" olarak nitelendirilmiş olan Ahmed Kemal Paşa'nın birkaç kitabı ve bir araya getirilmemiş olan birtakım şiirleri mevcuttur. Farsça, Almanca öğrenip dış politika alanında donanımını artırmıştır. Avrupa'daki çeşitli ülkelere özel vazifeyle gerçekleştirdiği seyahatlerinde özellikle modern eğitim unsurlarını yerinde görüp tecrübe etmiştir.

Ahmed Kemal Paşa'nın Tanzimat maarifinde üst düzey görevler üstlendiği dönem, 1847-1876 yılları arasındaki yaklaşık 30 yıllık bir süreyi kapsamaktadır. Dört farklı saltanat (Sultan Abdülmecid, Sultan Abdülaziz, V. Murad, Sultan II. Abdülhamid) dönemini ve çok sayıda farklı hükümeti kapsayan bu süreçte; eğitim reformu girişimlerini gerek yasamanın gerekse yürütmenin en üst mevkilerinde yer edinmek suretiyle yönlendirme fırsatı bulmuştur. Bu doğrultuda Osmanlı Devleti'nin modern reformlar yoluyla eski gücüne kavuşturulabileceği inancının hâkim olduğu bu evrede eğitim modernleşmesi girişimlerinin kişiler üstü bir devlet politikası olarak addedildiği görülmektedir. Buradan hareketle, Osmanlı eğitim modernleşmesi inisiyatifleri için istikrarlı bir yaklaşım benimsendiği ifade edilebilir. Bu politikanın doğal bir sonucu olarak modern eğitim düşüncesinin kurumsallaştırılmaya çalışıldığı bu dönemdeki eğitim modernleşmesi hareketlerinin bu bakış açısıyla yürütüldüğü söylenebilir. Ayrıca söz konusu sürecin, teorisyen ya da pratisyen kimliğiyle sürece katkı sağlayan Tanzimat bürokratlarının sayesinde şekillendiği gerçeğinden hareketle Osmanlı eğitim modernleşmesine öncü rolüyle önemli bir katkıda bulunan Ahmed Kemal Paşa'nın eğitim politika ve uygulamalarının incelenmesi büyük gereklilik arz etmektedir.

Bu araştırmanın amacı, Ahmed Kemal Paşa'nın Tanzimat Dönemi Osmanlı eğitim modernleşmesi sürecindeki politika ve uygulamalarının kapsamlı ve bütüncül bir şekilde incelenmesidir. Osmanlı eğitim modernleşmesi bağlamında öncü ve yön tayin edici bir eğitimci/bürokrat kimliğine sahip olan Kemal Paşa'nın teorisyen ve pratisyen rolleriyle ortaya koyduğu eğitim faaliyetleri yaşadığı dönemin tarihi kaynaklarına dayanılarak araştırımıştır. Bir başka ifadeyle Tanzimat Dönemi eğitim modernleşmesini 
anlamak için Kemal Paşa gibi önemli bir zatın portresindeki bugüne dek bilinmeyen/unutulan ayrıntıları ortaya çıkarmak ve buradan hareketle döneme ilişkin orijinal bilginin yanı sıra özgün bir değerlendirme sunmak amaçlanmıştır. Nitekim Ahmed Kemal Paşa gibi Osmanlı'da eğitimin modernleşmesi sürecinde kritik rol oynamış figürlerin çok yönlü biyografileri ortaya konulmadan ve onların, yaşadıkları dönemin eğitim politika ve uygulamalarına katkısını kapsamlı ve müstakil bir şekilde ele alarak analiz eden araştırmalar yapılmadan Tanzimat Dönemi Osmanlı eğitim modernleşmesini anlamak ve bu bağlamdaki çıktıları gelişimsel ve bütüncül bir bakışla değerlendirmek mümkün görülmemektedir.

Buradan hareketle bu araştırmada temel olarak şu araştırma sorusu üzerine odaklanılmıştır: Ahmed Kemal Paşa'nın maarif alanına yönelik olarak üst düzey devlet görevlerinde bulunduğu dönemlerde geliştirilen politikalar ve gerçekleştirilen uygulamalar nedir/nasıldır?

\section{YÖNTEM}

Nitel yaklaşımın kullanıldığı bu araştırma, özgün ve birincil kaynaklara dayalı bir eğitim tarihi araştırması olarak tasarlanmıştır. Osmanlı Devleti'nin 19. yüzyıldaki eğitim modernleşmesine reformist bir eğitimci ve bürokrat kimliğiyle katkı sağlamış olan Ahmed Kemal Paşa'nın devlet görevinde bulunduğu dönemlerdeki eğitim politika ve uygulamaları tarihsel olarak incelenmiştir.

\section{Veri Kaynakları ve Verilerin Toplanması}

Araştırma verileri, doküman incelemesi yoluyla toplanmış olup bu süreçte, Türkiye'de bulunan çok sayıdaki arşiv ve kütüphanede araştırma ve incelemelerde bulunulmuştur. İlgili literatür derinlemesine ve detaylı bir biçimde incelenerek Ahmed Kemal Paşa'ya ve onun yaşadığı döneme (1808-1887) ilişkin veriler saptanmış, konuya ilişkin bir arka plan, kuramsal ve kavramsal çerçeve oluşturulmuştur. Türkiye Cumhuriyeti Cumhurbaşkanlığı Devlet Arşivleri Başkanlığının İstanbul ve Ankara'da bulunan arşiv merkezlerindeki araştırma fonları üzerinde yapılan taramalar neticesinde Ahmed Kemal Paşa'nın farklı tarihlerde sürdürdüğü üst düzey eğitim yöneticiliği görevlerinde ortaya koyduğu politikalar hakkında bilgi sunan ve özellikle de kendisinin mühür ve imzasını taşıyan çok sayıda arşiv belgesi tespit edilmiştir. Araştırma konusuyla ilgili temin edilen söz konusu belgeler, araştırmanın esas veri kaynağını oluşturmaktadır. Bunun yanı sıra verilerin geçerliğini ve güvenirliğini artırmak için veri kaynaklarını çeşitlendirme (Denzin ve Lincoln, 2005) hususuna özellikle dikkat edilmiş olup çok sayıda hatırat, günlük, yerli-yabancı gazete haberleri, resmi istatistik kayıtları ve devlet yıllıkları incelenerek araştırmanın veri setine dahil edilmiştir.

Veri toplama sürecinde araştırmanın geçerliği ve güvenirliği hususlarında önlemler almaya ayrı bir önem gösterilmiştir. Bu çerçevede, temel olarak, araştırma sürecinde kullanılan tüm kaynakların geçerli tarihsel bilgiyi sağlama potansiyelleri tartışılmış ve gerekli sorgulama yapıldıktan sonra araştırmaya dahil edilmiştir. Bunun yanı sıra Kemal Paşa'yla ilgili ortaya çıkarılan verilere ilişkin, araştırmanın referans kaynakları arasında karşılaştırma yapılmak suretiyle tutarlılık ve güvenirlik sorgulaması yapılmıştır. Şöyle ki Kemal Paşa'ya iliş̧in arşiv belgelerindeki veriler, hem diğer birincil kaynaklarla hem de (ayrıntılı ve kapsamlı literatür taramasıyla elde edilen) kuramsal ve kavramsal bilgi sağlayan eserlerle karşılaştırılmıştır. Böylelikle tutarlı ve güvenir bilgiye ulaşılmaya çalışılmıştır.

\section{Verilerin Analizi}

Araştırma kapsamında belirlenmiş Osmanlı Türkçesiyle yazılı dokümanların temin edilmesinin ardından bu dokümanların analize hazırlanması sürecinde; odaklı tarama, tasnif ve tahlil çalışmaları ile transkripsiyon ve transliterasyon çalışmaları gerçekleştirilmiştir. Elde edilen veri setinin çözümlenmesi sürecinde içerik analizi yöntemi kullanılmıştır. Ahmed Kemal Paşa'nın Osmanlı Devleti'nin maarifle ilgili politika ve uygulama alanlarındaki hizmetleriyle ilgili tarihsel kayıtların analizinde eksensel veya eksenel kodlama olarak ifade edilen analiz yöntemi kullanılmıştır (Strauss ve Corbin, 1998). Öncelikle verilerin analize hazırlanması aşamasında oluşturulan kavram listesi (eğitim politikası türleri, politika oluşturma aşamaları, eğitim politikası uygulama araçlarına ilişkin kavramları içeren) kullanılmıştır. Aynı zamanda analiz sürecinde ortaya çıkan yeni kavramlar da dikkate alınarak bu liste analiz süreci bitene kadar dinamik bir şekilde yenilenmiştir.

Analiz süreci sonunda ortaya çıkan bulgular, daha sonra karşılaştırmalı bir biçimde değerlendirilmiştir. Tarih ve eğitim bilimleri alanının gerektirdiği bilimsel yöntem ve yaklaşımlar çerçevesinde multidisipliner ve bütüncül bir şekilde gerçekleştirilen analizler yine bu doğrultuda değerlendirilmiştir. Bu değerlendirme esnasında, Tanzimat'tan Cumhuriyet'e Osmanlı eğitim politikalarının modernleşmesini konu alan literatür dikkate alınmıştır. Buradan hareketle yeni ve analitik değerlendirmelere ulaşılmaya çalışılmıştır. Ayrıca söz konusu tarihsel dönemin siyasi, ekonomik, sosyal ve ekonomik konjonktürü göz önünde bulundurulmak suretiyle elde edilen analiz sonuçları çoklu bakış açısıyla değerlendirilmeye çalışılmıştır. Ahmed Kemal Paşa’nın yaşadığı dönemin maarif hayatına etkisi tespit edilirken doğrudan kendisinin etkisiyle gelişen maarif faaliyetleri özellikle belirtilmiştir. Bunun yanı sıra eğitime ilişkin nazırlık dönemini kapsayan fakat kendisinin ne derece dahli olduğu bilinmeyen faaliyet ve konulara da gerekli açıklamalar yapılmak suretiyle yer verilmiştir. 


\section{BULGULAR}

Araştırma bulgularının sunulduğu aşağıdaki bölümde yer alan alt başlıklarda, Ahmed Kemal Paşa'nın maarifle ilgili üst düzey eğitim yöneticiliği görevlerini sürdürdüğü Tanzimat Dönemi'nde geliştirilen eğitim politikaları ve gerçekleştirilen uygulamalara yer verilmiştir.

\section{Mekatib-i Umumiye Muavinliği Dönemi (1847-1848)}

Tanzimat Dönemi'nde maarif alanında belirli bir sistem oluşturmaya yönelik olarak Meclis-i Maarif-i Umumiye tarafından geliştirilen politikaları uygulamaya koymak amacıyla ilk olarak Mekatib-i Umumiye Nezareti kurulmuştur. Bu kuruma nazır olarak Sahaflar Şeyhizade Mehmed Esad Efendi atandı̆̆ı gibi Esad Efendi'nin maiyetine ise o sıralarda Sadaret Mektubi Kalemi Mümeyyizliği ve Farsça Tercümanlığı görevinde bulunan Ahmed Kemal Efendi* -ilave memuriyetle- muavin olarak 3 Ocak 1847 tarihinde atanmıştır (BOA. I..DH. 134/6903; BOA. I.DH. 135/6923; Maarif Salnamesi, H. 1316/M. 1898-1899, s. 24). Esad ve Kemal Efendilerin bu görevlerinin yanı sıra Meclis-i Maarif-i Umumiyenin de doğal üyeleri oldukları bilinmektedir (BOA. A.MKT. 91/52). Kemal Efendi'nin söz konusu üyeliği 1848 yılında Mekatib-i Umumiye Müdürlüğüne atandıktan sonra da devam etmiştir. Böylelikle 1847 yılından itibaren Berlin Elçiliğine tayin edildiği 1854 yılına kadar hem Mekatib-i Umumiye Nezaretindeki yöneticilik göreviyle hem de Meclis-i Maarif-i Umumiyedeki üyelik göreviyle Osmanlı maarif hayatına önemli hizmetlerde bulunarak Tanzimat modernleşmesinin reform politikalarının üretildiği birimlerde görev almıştır.

Kemal Efendi'nin Maarif-i Umumiye Nezaretinde Muavinlik görevi 3 Ocak 1847- 26 Aralık 1847 tarihleri arasında yaklaşık bir yıl kadar sürmüştür. Bu dönemdeki eğitim politika ve uygulamalarını 1845 yılında kurulan Meclis-i Maarif-i Muvakkatin ortaya koyduğu ve Tanzimat Dönemi eğitim politikalarının gelişimine esas oluşturan kararlar çerçevesinde açıklamak önemli görülmektedir. Nitekim söz konusu kararlar ilk, orta ve yükseköğretim olarak tasnif edilen eğitim kademelerinde yapılacak reformlara ilişkin politika ve uygulamaları içermektedir (Maarif Salnamesi, H. 1321, s. 18,-19; Cevdet Paşa, 1991, s. 37-38; Mahmud Cevad, 2002, s. 21). Dolayısıyla (Nazır) Esad ve (Muavin) Kemal Efendilerin yöneticiliğindeki Mekatib-i Umumiye Nezaretinin bu dönemdeki eğitim faaliyetlerini adı geçen Meclisin çalışmaları neticesinde belirlenen genel eğitim politikaları bağlamında değerlendirilebilir.

Bu dönemde Sultan Abdülmecid'in emir ve iradesi gereği ile Meclis-i Maarif-i Muvakkatin önerisi üzerine Meclis-i Maarif-i Umumiye tarafından ilköğretim reformu kapsamında bir talimatname hazırlanmıştır. Sıbyan Mektebi Hocalarına Talimat olarak ifade edilen bu resmi belgenin hazırlanışında Ahmed Kemal Efendi'nin yoğun çaba ve gayretlerinin olduğu ifade edilmektedir (Inal, 1969, s. 1150). Bununla birlikte muavinlik görevini sürdürdüğü ve aynı zamanda Meclis-i Maarif-i Umumiye Üyeliğinde bulunduğu dönemde son şekline kavuşan söz konusu Talimatname 8 Nisan 1847 tarihinde yayımlanmıştır (Akyüz, 1994; Unat, 1964, s. 200; Binbaşıoğlu, 1996, s. 7-10; Kara ve Birinci, 2012, s. 451). Talimatname sıbyan mekteplerine dair ders araç ve gereçleri, öğretim yöntemi, öğrenim süresi, sınavlar, disiplin kuralları gibi birçok konu hakkında oldukça önemli yenilik kararlarını içinde barındırmaktadır. Bu haliyle Osmanlı modern eğitim sistemi dahilinde bu kapsamda yayımlanan "ilk" öğretim programı olduğu ileri sürülebilir (Şahbaz, 2005, s. 31). Osmanlı bireylerinin sıbyan mekteplerindeki eğitim öğretim süreçlerinin nasıl işleyeceğine, hocaların bu süreçteki görev ve sorumlulukları ile yaklaşım ve yöntemlerine ilişkin belirlenen esasları ihtiva eden Talimatname'nin temel amacı geleneksel eğitim öğretim düzeninde yeni ve modern reformlar yapmak suretiyle bireylerin kısa sürede ve kolay bir şekilde eğitim kazanmalarıdır. Buna uygun olarak sıbyan mekteplerinde nitelik geliştirmeye ilişkin ders araç gereçlerinin sağlanması teşebbüsünde bulunulmuş (BOA. A.MKT. 71/19; BOA. I.DH. 162/8438, 4-1,) olmakla birlikte bu süreçte önemli problemler yaşanmış olup Talimatname'nin diğer hükümleri tam anlamıyla uygulamaya geçirilememiştir.

Kemal Efendi'nin Mekatib-i Umumiye Muavinliği görevine atandı̆̆ı Ocak 1847 tarihinden sonra ortaya koyduğu ilk icraatlarından biri, Osmanlı ülkesinin ilk modern (sivil) rüştiye mekteplerini açmak için girişimde bulunmak olmuştur*. Bu fikre bu denli nasıl sarıldığı bilinememekle birlikte hayli emek ve gönül verdiği bu işin altından kalkabileceğine yönelik etrafında güvenoyu oluşmuştur. Öyle ki Ahmed Cevdet Paşa'nın meşhur eseri Tezâkir'de de belirtiği üzere, “...Kemal Efendi erbâb-ı ma'ârifden bir zât olup bu işin ehli..." bir kişidir (Cevdet Paşa, 1991, s. 37). Kemal Efendi, gerek söz konusu güvenoyunun dayanak sağlayan etkisi gerek kendi aydın ve cevval profil özelliklerinin farkında olarak başarıya ulaşma hedefinde bunun kendisine güven sağlaması ve gerekse de Mustafa Reşid Paşa gibi üst düzey devlet adamlarının direktif, yönlendirme veya teşviklerinden güç alması... sebebi her ne olursa olsun etkisi çağını aşan oldukça önemli bir eğitim uygulamasına imza atmıştır. Osmanlı tebaasının örgün eğitimi için rüştiye mekteplerini kurmuştur. Bu doğrultuda 25 Şubat 1847 tarihinde Sadaret makamından almış olduğu izinle i̇stanbul'da Davudpaşa'da bulunan Nazperver Kadın Mektebi adındaki eski bir sıbyan mektebini rüştiyeye dönüştürmüştür (Bilim, 2002, s. 225; Kaya Doğanay, 2011, s. 29). Böylelikle sıbyan mekteplerinin üstünde yeni bir eğitim kademesi olarak planladığı rüştiyelerin pilot uygulamasını başlatmıştır. Daha sonra bu girişimin devamlılı̆ını sağlamak yani başkent İstanbul başta olmak üzere ülkenin hemen

\footnotetext{
* Paşa unvanı, Ahmed Kemal'e 1870 yılında İran'a görevlendirildiği sırada verilmiştir (BOA. i.DH. 617/42969, (H. 20 Cemaziyelevvel 1287 / M. 18 Ağustos 1870).

* 1839 yılında açılarak faaliyete başlamış olan Mekteb-i Maarif-i Adliye ve Mekteb-i Maarif-i Edebiye de rüştiye olarak adlandırılmış ve ilköğretimin bir üst kademesine yönelik olarak planlanmış kurumlar olmasına rağmen bu mektepler daha çok mesleki eğitim kapsamında memur yetiştirme amacıyla kurularak 1862'de kapatılmış olan mekteplerdir (Yıldııı, 2010, s. 14-29). Öte yandan halkın formal-örgün eğitimine yönelik olarak Kemal Efendi'nin usul-i cedit yaklaşımıyla 1847'de İstanbul'da açtığı ve Tanzimat'tan Cumhuriyet'e giden süreçte tüm Osmanlı ülkesinde yaygınlaștırılan mektepler ise ilk modern rüștiye mektepleri olarak Türk eğitim tarihindeki yerinialmıștır.
} 
her yerinde modern örgün eğitim çerçevesinde faaliyet gösterecek olan rüştiye mekteplerini yaygınlaştırmak için büyük çaba göstermiştir. Kemal Efendi, kuruculuğunu üstlendiği söz konusu rüştiye mekteplerinde bizzat hocalık da yapmıştır. Bununla birlikte rüştiyelerde okutulmak üzere Farsça öğretimi için Talim-i Farisî adında bir ders kitabı hazırlamıştır. Ayrıca ilim ve irfanına güvendiği dönemin bazı kalem erbaplarını ders kitabı yazmaları konusunda teşvik etmiştir. Bu çerçevede Ahmed Cevdet Efendi Ma'lûmât-ı Nâfıa adlı eserini bu dönemde, Kemal Efendi'nin teşvikiyle yayımlamıştır (Cevdet Paşa, 1991, s. 39; Fatma Aliye, 1995, s. 55).

Davudpaşa Rüştiyesinin beklendiği şekilde fayda gösterdiği anlaşılınca uygun mahaller tespit edilerek Bayezid, Üsküdar, Tophane ve Babıali civarındaki Ağa Camii'nde olmak üzere dört rüştiye mektebinin daha açılmasına karar verilmiştir. Ayrıca bu mektepler için 13 Aralık 1847 tarihinde bütçe tahsis edilmiş olup aylık 75 kuruş maaşla çalıştırılmak üzere birer bevvap görevlendirilmiş; mektep binası ve derslikler için gerekli bilumum eşyalar temin edilmiştir (BOA. I.DH. 162/8438, 3-1, 4-1). Kemal Efendi'nin olağanüstü gayretleriyle İstanbul'da 1847-1848 yıllarında açılan bu modern mektepler ülkede daha sonra kurulan rüştiyelere numune olarak öncülük etmiştir (Akyüz, 2006, s. 25). İstanbul'daki ilk rüştiyelerle hemen aynı tarihlerde (22 Temmuz 1847) Trablusgarp ile Bingazi'de de rüştiye Mektebi kurulması, Kemal Efendi'nin de aralarında bulunduğu Meclis-i Maarif-i Umumiye üyelerinin müzakeresi neticesinde kararlaştırılmıştır (BOA. A.MKT. 91/52). Dolayısıyla bu süreçteki kararların rüştiye mekteplerinin yaygınlaştırılmasına yönelik olarak daha sonraki devlet politikalarına da öncülük ettiği çıkarımında bulunulabilir.

Eğitim sisteminin ilk ve orta kademesine ilişkin belirtilen düzenlemelerin yanı sıra yüksek kademesi için de İstanbul'da bir Darülfünun kurulması kararlaştırılmıştır. Tabii bu kararın arka planında Tanzimat'ın mucidi Mustafa Reşid Paşa'nın önemli bir katkısı olup Batı'da olduğu gibi üç kademeli bir eğitim sistemi yapılandırması amacıyla gerekli siyasi ve idari koşulların oluşturulması için çaba sarf etmiştir (Kaplan, 1994, s. 119). Darülfünun'un kuruluşuna yönelik olarak Avrupa'daki üniversitelere benzer şekilde büyük ve gösterişli bir bina yapılması planlanmıştır. Bunun için çok geçmeden bir girişimde bulunularak Italyan asıllı Mimar Gaspare Trajano Fossati (Eyice, 1996, s. 170-173) ile İstanbul'da bir bina inşası için Kasım 1846'da mukavele yapılmıştır (BOA. HR.TO. 407/9; BOA. HR.TO. 567/65). Bu doğrultuda Ayasofya civarında belirlenen büyük bir arazi üzerine üç katlı, 125 odalı ve oldukça gösterişli bir bina yapımına hemen başlanmıştır*.

1847 yılında Mecliste görüşülerek kararlaştırılan konulardan birisi de öğretmen yetiştiren modern bir mektep kurma projesidir. Kemal Efendi'nin girişimleriyle kurulan rüştiye mekteplerinin faaliyete geçmesi üzerine bu mekteplerin öğretmen ihtiyacı da açığa çıkmış ve öğretmen ihtiyacını giderecek bir kurum olarak Darülmuallimîn fikri ortaya atılmıştır. Bu çerçevede ilk defa "Darülmuallimîn" kavramının, oldukça çalışkan ve yenilikçi biri profile sahip Kemal Efendi tarafından Takvim-i Vekayi'de yayımlanan Fransız mektepleri hakkında bilgi veren bir yazıda kullanıldığı ifade edilmektedir (Takvim-i Vekayi, no: 361; Akt: Erdoğdu, 1996, s. 201). Darülmuallimînle ilgili olarak Meclis-i Maarifin hazırladığı 25 Temmuz 1847 tarihli bir mazbatada, nitelikli öğretmene duyulan ihtiyaç açık bir biçimde vurgulanmış; her tür bilim ve fenni öğretmeye gücü yeten nitelikli öğretmenler yetiştirilmesi gerektiğinin altı çizilmiş; eğitim ve öğretim yöntemlerini bilen bilgili öğretmenlerin yetiştirilmesinin eğitim alanındaki düzenlemeler içinde en önde gelen hususlardan biri olduğu belirtilmiştir. Bu gerekçelerden hareketle Darülmuallimîn adında öğretmen yetiştiren bir okul açılması kararlaştırılmıştır (BOA. İ.DH. 8034; Akt: Akyüz, 2006, s. 17-58).

\section{Mekatib-i Umumiye Nazırlığı Dönemi (1848-1854)}

Kemal Efendi, 1845 yılı itibarıyla hız kazanan maarif modernleşmesi sürecinde hem reform politikaları üretme alanında cevval bir bürokrat hem de oluşturulan politikaların sağlam ve titiz bir uygulayıcısı olduğunu ortaya koymuştur. Yaklaşık bir yıl kadar süren Mekatib-i Umumiye Nezaretindeki Muavinlik görevi boyunca Kemal Efendi'nin Osmanlı maarifine yapmış olduğu hizmetler, yaşadığı dönemde oldukça dikkat çekici bulunmuştur. Bilhassa rüştiye mekteplerinin kuruluşunda üstlendiği aktif rolün vesilesiyledir ki 26 Aralık 1847 tarihinde Mekatib-i Umumiye Nazırı Esad Efendi’nin görevden ayrılışının akabinde, söz konusu makam -müdürlük unvanıyla- Kemal Efendi'nin uhdesine verilmiştir. Kısa bir süre sonra rüştiye mekteplerinin başarısı görülünce müdürlük unvanı yeniden nazırlığa dönüştürülmüş ve memuriyet derecesi Rütbe-i Saniyeye yükseltilmiştir. Kemal Efendi, Mayıs 1854 tarihinde Osmanlı Devleti-Berlin Ortaelçiliğine atanıncaya kadar bu görevini sürdürmüştür. Tanzimat Dönemi Osmanlı maarif modernleşmesinin esas unsurlarını oluşturan politikaların etkisi çerçevesinde, Mekatib-i Umumiye Nazırı Kemal Efendi'nin öncülüğüyle hayat bulan eğitim politika ve uygulamaları dikkate değerdir.

1848 yılı başlarında Mekatib-i Umumiye Müdürlüğüne atandıktan sonra Kemal Efendi'nin ilk icraatı, daha önce muavinlik görevindeyken kurduğu Davudpaşa Rüştiyesine ek olarak, Bayezid, Üsküdar, Tophane ve Babıali civarındaki Ağa Camiinde olmak üzere dört rüştiye mektebinin daha faaliyete geçirilmesi olmuştur. Yakından ilgilenerek büyük emek sarf ettiği (Berker, 1945, s. 5) bu mektepler Osmanlı'nın örgün sivil eğitimine yönelik rüştiye mektepleri olarak tarihteki yerini almıştır. Kuruluşuyla birlikte eğitim öğretim faaliyetlerine hızlı bir şekilde başlayan bu mekteplerde, ilk eğitim öğretim döneminin Temmuz 1848'de tamamlanmasının ardından 20 kadar öğrenci, Meclis-i Maarif-i Umumiyede bir sınava tabi tutulmuştur. Öğrencilerin sınavda gösterdikleri başarı Meclis tarafından takdire şayan görülmüş ve bu durum devrin padişahı Sultan Abdülmecid'e arz edilmiştir. Akabinde rüştiye mektebi öğrencilerinin sınav başarısı, maarif alanında modernist ve reformist politika ve uygulamaların öncüsü ve destekçisi olma yaklaşımıyla öne çıkan Sultan'ın ilgisini çekerek söz konusu sınavın, kendisinin huzurunda tekrar uygulanmasını istemiştir. Bunun üzerine Babıali'de bulunan Meclis-i Vala-yı Ahkam-ı Adliye odasında, Sultan'ın ve diğer üst düzey devlet adamlarının huzurunda

\footnotetext{
* Ancak bu girişimden kısa vadede sonuç alınamamıştır. Söz konusu binanın inşaatı çok uzun sürmüş, 8 Mart 1865 tarihinde bitirilebilmiştir. İnşaat tamamlandığı zaman ise Darülfünun olarak kullanılmamıs, devlet sistemindeki farklı bürokrasi birimlerine mekan olmuștur (ERGiN, 1977, s. 546).
}

| Kastamonu Eğitim Dergisi, 2020, Vol. 28, No. 6| 
sınav uygulaması yeniden gerçekleştirilmiştir. Sultan'ın beğeni ve övgüsünü kazanan bu uygulama sonrasında mektebin öğretmen ve öğrencileri atiyye-i seniyye ile ödüllendirilmişlerdir. Yaşanan bu gelişmeler Kemal Efendi'nin makam ve rütbesinin yükseltilmesinde etkili olmuştur. Bu sayede Kemal Efendi'nin müdürlük unvanı nazırlığa dönüştürülmüş ve memuriyet kademesi yükseltilmiştir (BOA. A.MKT.MVL. 9/A.58; Pakalın, 1993, s. 65-68).

Mekatib-i Umumiye Nazırı Kemal Efendi'nin döneminde rüştiye mekteplerinin başta İstanbul olmak üzere tüm ülke sathında yaygınlaştırılarak sayısının artırılmasına yönelik girişimlerde bulunulmuştur. Bu kapsamda İstanbul'da yeni açılan rüştiyelere ilave olarak Beşiktaş sahilinde Hayrettin Paşa Medresesiyle Kasımpaşa'da bulunan Piyalepaşa Mektebinin rüştiye mektebine dönüştürülmesi planlanmıştır. Bu türden girişimlerin sonucunda İstanbul'da 1852 (Devlet Salnamesi, H. 1269/M. 1853/1854, s. 8788), 1853 (Devlet Salnamesi, H. 1270/M. 1854/1855, s. 94-95), 1854 (Devlet Salnamesi, H. 1271/M. 1855/1856, s. 104-105) yıllarında faaliyet gösterdiği bilinen rüştiye mektepleri şunlardır: Bayezid Rüştiyesi, Sarachane Rüştiyesi, Laleli Rüştiyesi, Davudpaşa Rüştiyesi, Üsküdar Rüştiyesi, Beşiktaş Rüştiyesi, Kasımpaşa Rüştiyesi. Bu süreçte Osmanlı ile Rusya arasında yaşanan $1853-1856$ Kırım Savaşı́nın etkileri de dikkate alındığında dönemin siyasi, ekonomik ve sosyo-kültürel koşulları çerçevesinde rüştiye mekteplerini yaygınlaştırma çalışmalarının devam ettirildiği anlaşılmaktadır. Bu çerçevede Sultan Abdülmecid’in 1845 yılındaki fermanında devletin uzun vadeli bir politikası olarak belirlenen maarifin ülke çapında intişarı amacına uygun olarak (Engelhardt, 2017, s. 83) sadece İstanbul'da değil başkent dışındaki diğer Osmanlı şehirlerinde de eğitimin yaygınlaştırılması politikası benimsenmiştir.

Taşrada rüştiyelerin kurulması şeklinde zuhur eden bu politikanın, 1848 yılında belirlendiği ve bu doğrultudaki girişimlerin başlatıldığı görülmektedir. Fakat rüştiyeler, ilk kademenin üstünde bir mektep türü olarak yapılandırıldığından ötürü bunların taşraya yaygınlaştırılması için öncelikli olarak ilk kademede yer alan sıbyan mekteplerinde bazı düzenlemeler yapılması gerektiği ortaya çıkmış ve yapılan incelemeler neticesinde sıbyan mektebi hocalarının eğitim yaklaşımlarına yenilik katma ve bu mekteplere ders araç gereçleri temin etme kararı alınmıştır. Belirlenen bu politikaya göre sıbyan mektepleri için gerekli düzenlemelerin ardından taşradaki şehirlerde bulunan büyük sıbyan mekteplerinden bir tanesi seçilerek rüştiyeye dönüştürülecektir. Sıbyan mekteplerinde dini bilgiler ve okuma eğitimini başarıyla tamamlayan öğrenciler söz konusu yeni rüştiye mektebine alınacaktır. Bununla birlikte rüştiye mektebine Darülmuallimîn mezunlarından bir muallim ile mahallî ulemadan kabiliyetli bir kişi muallim yardımcısı olarak tayin edilecektir. Bu plan doğrultusunda ilk olarak Bursa ve Edirne'de birer rüştiye mektebi açılmasına karar verilmiştir (BOA. IMVL. 127/3324; Akt: Altınova, 2010, s. 124). Böylelikle buradaki uygulamaların taşradaki tüm şehirlere örnek olacağı ve bu yolla rüştiye mekteplerinin ülke sathında kolayca yaygınlaştırılabileceği düşünülmüştür. Darülmuallimîn mezunlarının mektepteki eğitim öğretim faaliyetlerinden esas sorumlu muallim sıfatıyla, yöre ahalisinden geleneksel eğitime mensup hocaların ise yardımcı muallim olarak rüştiyelere atanmasına yönelik alınan bu kararlar, rüştiye mekteplerinde Tanzimat Dönemi boyunca uzun süre uygulanmış bir politika olması bakımından önemli ve dikkat çekicidir. Öyle ki bu yönde alınan ilk kararlar, rüştiyelerin yaygınlaştırılması ve rüştiyelere muallim atamasına ilişkin daha sonraki dönemlerde belirlenen usul ve esaslara temel oluşturmuştur.

Söz konusu politika belirtildiği şekilde önemli olmasına rağmen Bursa ve Edirne'de açılması kararı alınan rüştiyeler her nedense açılmamış; bunun yerine taşradaki ilk rüştiye mektepleri Bosna Eyaletinde açılarak faaliyet göstermiştir. Bu çerçevede Bosna Eyaletinin yeni teşkil olunan beş livasının kaymakamlık merkezlerinde birer rüştiye mektebi açılması ve buraya personel tayin edilmesi kararlaştııılmıştır. Bu kararların çok geçmeden uygulamaya geçirildiği ve bazı merkezlerde açılması planlanan rüştiye binalarının yapım çalışmalarının 28 Mart 1852 tarihinde devam ettiği anlaşılmaktadır. Bununla birlikte Saray şehrinde ve Hersek Sancağının merkezi olan Mostar şehrinde planlanan rüştiye mekteplerinin bina yapımına başlanması ve bu mekteplerin inşa masraflarıyla muallim ve diğer personelin maaşlarının ahali tarafından karşılanması kararlaştırılmıştır. Bunun yanı sıra mekteplere Darülmuallimîn mezunlarından seçilmek suretiyle atanacak muallim-i evvellerin, atandıkları mektepte aynı zamanda müdürlük vazifesini de yerine getirmesi istenmiştir. Müdür/muallim-i evveller, vali ve liva meclisinin de katılımlarıyla gerçekleştirilecek öğrenci sınavlarına dair evrakların İstanbul'a gönderilmesi işinden sorumlu tutulmuştur (BOA. A.AMD. 36/89, 1-1; BOA. A.MKT.NZD. 54/28; BOA. A. MKT. MVL. 41/69; Kaya Doğanay, 2011, s. 75). Son olarak öğrencilerin öğretim süreçlerinde kullanacakları ders kitaplarının da merkezden gönderileceği belirtilmiştir (BOA. A.AMD, 36/89; Akt: T.C. Başbakanlık Devlet Arşivleri Genel Müdürlüğü, 1992, s. 452).

İstanbul'da 1847 yılından itibaren kurulan modern rüştiye mekteplerinin eğitim öğretime başlamasıyla birlikte bu mekteplerin en önemli ihtiyacının planlanan maarif modernleşmesine nefer olacak nitelikte öğretmenler olduğu anlaşılmıştır (Takvim-i Vekayi, H. 23 Rebiülahir 1264/M. 29 Mart 1848; Mahmud Cevad, 2002, s. 29-30. Akyüz, 2006, s. 28). Bunun üzerine gerekli hazırlıkların tamamlanmasının ardından rüştiye mekteplerine modern usullerde yetiştirilmiş nitelikli öğretmenlerin yetiştirileceği bir kurum olarak 16 Mart 1848 tarihinde Darülmuallimîn açılmıştır. Darülmuallimînin açılışında Sadrazam Mustafa Reşit Paşa'nın destekleri ile birlikte dönemin Mekatib-i Umumiye Nazırı Kemal Efendi'nin ciddi katkıları olduğu bilinmektedir (Koçer, 1991, s. 56; Akyüz, 2006, s. 28; Ünal ve Birbudak, 2013, s. 13; BOA. I.DH. 155/8034; Akt: Yıldırım, 2012; Duman ve Dilaver, 1996, s. 651-658). Mahmud Cevad, "Kemal Efendi'nin icraat-ı maarif-perverânesinin en mühimlerinden biri(nin)... Darülmuallimîn tesisi..." olduğunu vurgulamaktadır (Mahmud Cevad, 2002, s. 29). Hatta Darülmuallimînin isim babasının da Kemal Efendi olduğu (Türkiye Büyük Millet Meclisi (TBMM), 1997, s. 107) ve bu kavramı Fransız mektepleri hakkında bilgi verdiği Takvim-i Vekayi gazetesindeki bir yazısında ilk defa ortaya attığı ifade edilmektedir (Takvim-i Vekayi, no: 361; Akt: Erdoğdu, 1996, s. 201).

Kemal Efendi'nin Mekatib-i Umumiye Nazırlığı görevindeyken gerçekleştirdiği önemli faaliyetlerden bir diğeri ise Darülmaarif/Valide Sultan Mektebi adlı modern usullere göre eğitim veren bir mektep kurması olmuştur. Bütünüyle kendi projesi 
olarak bilinen bu mektebe, "Darülmaarif" adını vererek aynı zamanda mektebin isim babası olmuştur (BOA. i.DH. 224/13324; BOA. A.AMD. 26/23; TBMM, 1997, s. 107). 21 Mart 1850 tarihinde açılan bu mektebinin kuruluş amacl; açılması planlanan Darülfünun için öğrenci ve devlet hizmetleri için donanımlı memur yetiştirmektir (Takvim-i Vekayi, H. 23 Cemaziyelahir 1266/M. 6 Mayıs 1850; Akt: Mahmud Cevad, 2002, s. 32-33). Kemal Efendi, bu mektebi, daha önce kurulan rüştiye mekteplerinin üstünde, yükseköğretim kademesindeki Darülfünunun ise altında yer alacak bir kurum olarak tasarlamıştır. O sıralarda Avrupa'da var olan lise kademesindeki okullara denk olarak düşündüğünden dolayı bu mektebin açıış sürecindeki tüm yapılandırma faaliyetleriyle yakından ilgilenmiştir (Kara Pilehvarian, 2001; Demirel, 2009, s. 507-516; Sakaoğlu, 1994, s. 363-364). Hatta Darülmaarifte gerçekleştirilen eğitim öğretim faaliyetlerinde; çok sayıdaki öğrenci gruplarına en kısa sürede ve en ekonomik şekilde öğretim sağlamanın hedeflendiği, Amerikan menşeili bir öğretim modeli olan Lancaster öğretim sisteminin kullanıldı̆̆ı bilinmektedir (The Newcastle Journal, (28 Mayıs 1853), s. 3; Aksu, 2008, s. 60). Bu okulun kuruluşunda üstlendiği aktif rol, Kemal Efendi'nin parlak kariyer ilerleyişine hız kazandırarak başta Sultan Abdülmecid olmak üzere devrin erkân-ı ricalinden saygı görmesinisağlamıştır.

Kemal Efendi'nin nazırlığı döneminde, Osmanlı Devleti'nde idari ve askeri kadronun yetiştirilmesi için oluşturulan bir saray eğitim kurumu olan Enderun Mektebinin modernleştirilmesine yönelik bir reform çabasına girişildiği de görülmektedir. Kemal Efendi, Mekatib-i Umumiye Nazırı sıfatıyla Enderun mektebindeki mevcut durumunun iyileştirilmesi ve eğitim öğretim faaliyetlerinin yeniden düzenlenmesi için yapılması gerekenleri araştırmış; bunun neticesinde eğitim öğretim faaliyetlerinin modern usullere kavuşturularak nitelikli bir hale getirilebilmesi için birtakım öneriler geliştirmiştir (Ergin, 1977, s. 22-23). Buna göre mektepteki öğrenme ve öğretim sürecinde uygulanan modern ilke ve yöntemlerin istenilen seviyeye kavuşturulabilmesi için mevcut mektep personeline eğitimler verilmesi ve Darülmuallimînden (alanında uzman) bazı hocaların mektebe kısmi zamanlı olarak görevlendirilmesi kararlaştırımıştır (BOA. A.AMD. 32/5). 1851 yılında başlatılan bu girişimle birlikte Enderun Mektebindeki eğitim durumunun modern usullere göre yapılandırılarak rüştiye mektepleriyle benzer bir seviyeye çıkarılması arzu edilmiştir. Dolayısıyla Tanzimat'ın ilanıyla birlikte bir devlet politikası olarak ivme kazanan maarifin modernleştirilmesi uygulamaları kapsamında Enderun Mektebi de çerçeveye dahil edilmiştir.

Kemal Efendi'nin Ağustos 1850-Nisan 1851 tarihleri arasında Avrupa'ya bir görevlendirme sonucunda gidişi ise Tanzimat Döneminde benimsenen modern eğitim paradigmasının şekillendirilmesi noktasında oldukça önemlidir. Kemal Efendi bu görevlendirmesinde Paris, Londra, Brüksel, Köln, Berlin, Viyana ve Cenova gibi Avrupa şehirlerinde eğitim amaçlı gözlem ve araştırmalarda bulunmuştur. Bu seyahat için kendisine tanınan on aylık sürede, ilk olarak, Paris'te üç ay kalarak birtakım öğretim araç gereçleri temin etmiş ve Fransız okullarında gözlemde bulunmuştur. Bununla birlikte Londra, Brüksel ve Berlin başta olmak üzere diğer şehirleri ziyaret ederek eğitim amaçlı gözlem ve araştırmalarda bulunmuştur (2 Şubat 1851, BOA, A. MKT.MVL. 38/76; BOA, A.AMD. 32/78). Burada edindiği bilgi ve kazandığı deneyimleri ülkesine taşıyarak Osmanlı'da eğitimin modernleşmesi yolunda önemli uygulamaların başlatılmasını sağlamıştır. Kemal Efendi'nin Paris'ten satın aldığı ders araç gereçleri yeni kurulan rüştiye mekteplerinde kullanılmaya başlamıştır. Bu durum aslında Osmanlı eğitim reformlarına modern bir bakış açısı kazandırması yönüyle ele alınarak eğitim teknolojilerindeki modernizasyonun ilk uygulaması olarak değerlendirilebilir. Böylelikle Kemal Efendi, 1850'li yıllarda modernitenin Osmanlı eğitimine girişi için ilk uygulamalara öncülük etmekle kalmamış; bununla birlikte daha sonraki süreçlerde eğitim alanında atanmış olduğu üst düzey yöneticiliklerde, söz konusu eğitim reformlarının belli bir düzene oturtularak kalıcı politikalara dönüşmesi için de uğraşmıştır. Dolayısıyla onun, Avrupa eğitim sistemine ilişkin gerçekleştirdiği incelemelerin Osmanlı eğitim sistemine etkisi, tarihsel bir olgu olarak sonraki dönemlerde de devam etmiştir.

Kemal Efendi'nin nazırlığı sürecinde, Tanzimat Dönemi'ndeki modernleşme olgusunun bir sonucu olarak eser basım faaliyetlerine ayrı bir önem verildiği görülmektedir. Bizzat kaleme aldığı eserlerle dönemin eğitim-kültür hayatına katkıda bulunan Kemal Efendi, rüştiye mektebi öğrencilerinin yeni öğretim yöntemlerine uygun olarak kolay bir şekilde Farsça öğrenebilmeleri amacıyla Farisî Tekellüm Risalesi'ni yazmıştır (Ahmed Kemal, H. 1262 / M. 1846)* . Özellikle de bu sürecin önemli bir parçası olan Encümen-i Danişin kuruluşuyla birlikte eser basım faaliyetlerinin hız kazandığı anlaşımaktadır.

Bu dönemde kurulan Encümen-i Daniş adlı Osmanlı bilim akademisinin fikri temellerinin şekillendirilmesinde, Kemal Efendi'nin önemli bir payı olduğu bilinmektedir (Küçükler, 2014, s. 49-50). Nitekim Kemal Efendi'nin 1847 yılından itibaren eğitimde modernleşme bağlamında gerçekleştirdiği yenilikçi uygulamalar ve bu kurumun açılışından kısa bir süre önce eğitim alanındaki en yeni gelişmeleri gözlemleyip araştırmak amacıyla Avrupa'ya gönderilmesi, bu fikri destekler mahiyettedir. Ayrıca Kemal Efendi, Batı dünyasından eser tercüme etmeyi Tanzimat modernleşmesinin karakteristik bir özelliğine dönüştüren Encümen-i Danişin (1851-1862) dâhili üyeleri arasında da yer almıştır (Mahmud Cevad, 2002, s. 38. Kayaoğlu, 1996, s. 30-31).

\section{Birinci Maarif Nazırlığı Dönemi (1861-1862)}

1857 yılında kurulmuş olan Maarif-i Umumiye Nezaretinin ilk nazırı Abdurrahman Sami Paşa'nın görevinden ayrılmasının akabinde, onun yerine 24 Kasım 1861 tarihinde Ahmed Kemal Efendi atanmıştır. Bu yeni görevinden ötürü kendisine 30.000 kuruş maaş tahsis edilen (BOA. İ.DH. 499/33912) Kemal Efendi, "Rütbe-i Bala” ile ödüllendirilmiştir (BOA. A.DVN.MHM. 34/88). Daha sonra, 20 Şubat 1862 tarihinde kendisine ikinci rütbeden Nişan-ı Osmanî verilmiştir (BOA. A.DVN.MHM. 35/87). 18 Kasım 1862 tarihine kadar yaklaşık bir yıl süreyle yürüttüğü bu görevinin ardından Meclis-i Vala Üyeliğine atanmış olup Maarif Nazırlığı görevini bırakmak durumunda kalmıştır (BOA. i.DH. 499/33912).

\footnotetext{
* Bazı arşiv kayıtları, söz konusu eserin 1850'li yıllarda rağbet gören bir eser olarak alınıp satıldığı yani belli bir piyasası olduğunu göstermektedir (BOA. A.M. 9/33; BOA. A.MKT.NZD. 41/11).
}

| Kastamonu Eğitim Dergisi, 2020, Vol. 28, No. 6| 
Kemal Efendi'nin ilk defa atandığı söz konusu Maarif Nazırlığı dönemi incelendiğinde; yönetim politikaları, ekonomi politikaları, nitelik geliştirme politikaları, okullaşma politikaları ve eser basım ve yayımına ilişkin politikalar geliştirildiği görülmektedir. Yönetim politikaları arasından özellikle maarif nazırlığının organizasyonel yapısının oluşturulmasına yönelik olarak ciddi adımlar atılmıştır. Yetkili kişi ve kurumların belirlenmesine yönelik uygulamalar gereğince Takvimhane ve Tabhane Nezaretleri lağvedilmiş; buna dair tüm işlerden Maarif Nezareti/Nazırı sorumlu tutulmuştur (BOA. A.MKT.NZD. 398/25; BOA. A.MKT.UM. 539/94). Bu yapısal değişikliğe paralel olarak daha sonraki dönemlerde eser basım ve yayım faaliyetlerinin devlet kontrolü altında merkezi bir usulle sürdürülmesi için gerekli yasal düzenlemeler de gerçekleştirilmiştir.

Bu dönemde gerek nezaret bünyesinde personel atamaları gerekse de okul düzeyinde öğretmen atamalarına ilişkin çok sayıda vakaya ulaşmak mümkün olmakla birlikte, bunlardan hareketle eğitim personelinin atanma sürecine yönelik uygulamaların nasıl bir usulle gerçekleştirildiği de anlaşılabilmektedir (BOA. A.MKT.UM. 559/60; BOA. A.MKT.NZD. 422/37; BOA. I.DH. 493/33436; BOA. I.DH. 493/33491). Kemal Efendi'nin imzasını taşıyan çok sayıdaki arşiv belgesinden hareketle Maarif-i Umumiye Nezaretine memur, Meclis-i Maarif-i Umumiyeye üye ve mekteplere öğretmen atama ile personel maaş tahsislerinde Maarif Nazırının esas yetkili ve belirleyici kişi olarak rol oynadığı anlaşılmaktadır.

Kemal Efendi'nin bu nazırlık döneminde yeni mektepler kurmak suretiyle rüştiyeleri yaygınlaştırma politikasına devam edilmiştir (Mahmud Cevad, 2002, s. 61). Bu çerçevede; 1862 yılında Varna'da yeni bir rüştiye mektebi kurulmuş ve Rusçuk'ta bir rüştiye mektebinin inşasına başlanmıştır (BOA. MVL 954/41). Ayrıca bazı mektep binalarının tamir ve bakımlarının yapıldığı ve bu çerçevede İstanbul ile Galata, Üsküdar ve Eyüp'teki (Dersaadet ve Bilad-ı Selase) rüştiye mektepleri için ihtiyaç duyulan tamir ve bakım işleri ile masraflarının tespit edilerek buna dair oluşturulan raporların, (mekteplerin bağı bulundukları) vakıflar yoluyla bildirilmesi istenmiştir (BOA. A.MKT.NZD. 384/56). İstanbul mekteplerinin dışında Sırbistan gibi merkezden uzak bölgelerde de mektep tamir işlemlerinin gerçekleştirildiği bilinmektedir (BOA. A.MKT.NZD. 411/50).

Yaygınlaştırma politikalarının yanı sıra rüştiyelere ders araç gereçleri teminine yönelik faaliyetlere de hız kesmeden devam edilmiştir. Bu bağlamda Edirne'deki mektepler için ders kitabı temin edilmesi hususu üzerinde durulabilir. Edirne'de bulunan mekteplerde okutulmak üzere ahlak ve faydalı bilimlerle alakalı ders kitaplarına ihtiyaç duyulmuştur. Bu durumun ilgili üst birimlere bildirilmesi üzerine, ihtiyaç duyulan kitapların İstanbul'daki Maarif Kütüphanesinden temin edilerek gönderilmesi yönünde bir karar alınmıştır. Akabinde konu ile ilgili Maarif Nezaretine 25 Eylül 1862 tarihinde bildirimde bulunularak gereğinin yapılması istenmiştir (BOA. A.MKT.MHM. 241/29). Dolayısıyla ülkedeki mekteplerin ders araç gereçlerinin temini noktasında, Maarif Nezaretinin üstlendiği merkezi rolün bu dönemde de devam ettiği görülmektedir. Ayrıca Maarif Kütüphanesinin ders araç gereçleri temini noktasında lojistik bir merkez olarak faaliyet göstermiş olduğu anlaşılmaktadır.

Bu dönemde yeni bir okul türü olarak 21 Temmuz 1862 tarihinde Mekteb-i Aklam (Mahrec-i Aklâm, Mekteb-i Maârif-i Aklâm) kurulmuştur (Akyıldız, 2016, s. 238-240). 1862 yılında Mekteb-i Maarif-i Adliyenin lağvedilmesinin ardından kurulan Mekteb-i Aklam, rüştiye mekteplerinden mezun olduktan sonra devlet memuru olmak isteyenlerin eğitim gördüğü bir nevi hazırlık okulu olarak tasarlanmıştır.

\section{İkinci Maarif Nazırlığı Dönemi (1865-1867)}

Ahmed Kemal Efendi, 24 Nisan 1865 tarihinde ikinci kez Maarif nazırlığına atanmıştır (BOA. MB.I. 20/153; BOA. I.DH. 535/37188; BOA. A.MKT.MHM. 331/6). 24 Ağustos 1867 tarihinde Meclis-i Vala-yı Ahkam-ı Adliye üyeliğine atanıncaya kadar iki yıldan fazla bir süre bu görevi sürdürmüştür.

Bu nazırlık dönemi genel olarak değerlendirildiğinde; yönetim politikaları kapsamında Maarif Nazırlığının organizasyon yapısının oluşturulmasına yönelik uygulamalarda bulunulmuş olup özellikle de eğitim birimlerinin hiyerarşik yapısının belirlenmesine yönelik uygulamalar konusunda mesafe kat edilmiştir. Bu çerçevede 1846 yılında kurulmuş olan Meclis-i Maarif-i Umumiyenin politika üretme noktasındaki faaliyetleri Maarif Nazırı Kemal Efendi yönetiminde sürdürülmüştür. Yine eğitim yönetimi politikaları kapsamında özellikle taşrada çok sayıda rüştiye mektebi açılmasına ilişkin politikalar başarıyla izlenmiştir (Takvim-i Vekayi, H. 3 Haziran 1283/M. 15 Haziran 1867), Akt: Mahmud Cevad, 2002, s. 76). Yeni açılan rüştiyelere pek çok öğretmen ve hizmetli atamaları gerçekleştirilmiştir (BOA. I.MVL. 567/25498, 1-1; BOA. i.MVL. 532/23870, 2-1; BOA. A.MKT.MHM. 351/77; BOA. A.MKT.MHM. 363/46; BOA. i.MVL. 563/25280; BOA. İ.MVL. 566/25432; BOA. A.MKT.MHM. 373/57; BOA. i.MVL. 566/25480; BOA. I..MVL. 568/25545; BOA. I..MVL. 570/25593; BOA. İ.MVL. 570/25622; BOA. I.MVL. 571/25646; BOA. i.MVL. 567/25498). Atanan personellerin maaşları başta olmak üzere tüm özlük haklarına dair düzenlemeler Nezaret bünyesinde merkezi bir anlayışla gerçekleştirilmiştir. Bu doğrultuda Maarif Nezaretinin merkeziyetçi ve kurumsal özellikteki hüviyetini güçlendirme çabası güdüldüğü açıkça görülmektedir.

Araştırma kapsamında incelenen çok sayıdaki arşiv belgesinden yola çıkılarak 1865-1867 yılları arasında taşradaki bir mektebin muallim ihtiyacına nasıl çözüm bulunduğu, merkez-taşra arasındaki bürokratik yazışmaların nasıl cereyan ettiğini ve nihayetinde personel atamalarının nasıl gerçekleştiğini öğrenmek mümkündür. Osmanlı idari taksimatı içerisinde vilayete bağlı bir sancakta ve/veya sancağa bağlı bir kasabada açılması planlanan bir rüştiye mektebi için şehir ahalisinin aktif çalışmaları önemli olmuştur. Belirlenmiş olan uygulama prosedürü gereğince şehir ahalisinin maddi yardımlarıyla mektep olarak kullanılacak bir alan belirlenmesi gerekmiştir. Bu noktada kimi zaman şehir ahalisinden birtakım zengin kimselerin kimi zaman da şehirde görev yapan devlet memurlarının desteğiyle bir çeşit mektep kurma kampanyası başlatılmıştır. Şehirdeki devlet hizmetine tabi görevliler bu tür okul kurma faaliyetlerinin öncüsü konumunda bulunarak maddi ve manevi desteklerini celbetmek için halkı teşvik etmeye 
çabalamışlardır. Mektep kurulacak alan halkın kendi imkanlarıyla belirlenip eğitim öğretim faaliyetlerine elverişli hale getirildiği vakit, merkez-taşra arasında gerekli bürokratik yazışmalar başlatılmıştır. Bu kapsamda şehir ahalisinin yeni kurulacak mektep için personel ve bütçe tahsisi talepleri (veya mekteplerle ilgili yaşanan sorunlar) sancak mutasarrıflıkları aracılığıyla merkeze/ Sadaret Makamına bildirilmiştir. Bu noktada resmi yazışmalardaki ast-üst idari birimler arasındaki ilişkiye uygun olarak taşradan gelen dilekçeler Sadaret makamından Maarif Nezaretine gereği yapılmak üzere havale edilmiştir. Sonrasında Maarif Nezaretinde görüşülüp nasıl bir uygulama izleneceğine dair çalışma yapılmıştır. Maarif Nezaretince gerçekleştirilecek uygulama belirlendikten sonra nazırın imzasını taşıyan konuyla ilgili belge, Meclis-i Vala tarafından görüşülmek üzere Sadaret makamına gönderilmiştir. Meclis-i Valada değerlendirmeye alınan konunun, daha önce gerçekleştirilmiş uygulamalarla uygunluğu incelenerek karara bağlanmıştır. Ayrıca Meclis-i Vala, söz konusu mekteplerin ihtiyaca yönelik olup olmadığını ve taleplerin usule uygunluğunu incelemiştir. Bu noktada, Padişahın irade-i seniyyesi gereğince tüm Osmanlı memleketlerinde rüştiye mekteplerinin yaygınlaştırılması politikasına uygun olarak belirlenmiş prosedürler çerçevesinde mekteplerin öğretmen ataması ve diğer ihtiyaçlarının karşılanması kararlaştırılmıştır. Sonrasında bu yöndeki kararlar padişahlık makamına sunulmuştur. Padişahın oluru alındıktan sonra Sadaret Makamı aracılığıyla ilgili birimlere, gerekli uygulamanın gerçekleştirilmesi için bildirimde bulunulmuştur. Bu bağlamda Maarif ve Maliye Nezaretlerine gönderilen yazılarda, ilgili rüştiye mektebine atanacak muallime ilişkin maaş, kadro durumu vs. bilgiler sunularak gerekenin yapılması istenmiştir. Nihai kertede merkezde verilen kararlar taşraya bildirilerek bürokratik süreç tamamlanmıştır.

Yeni bir okul türünün kuruluşuna ilişkin politikalar kapsamında Kemal Efendi'nin bu dönemdeki en önemli uygulamalarından biri, Lisan Mektebi'nin kuruluşu olmuştur. Osmanlı'nın modern bir dil okulu olarak yapılandırılmış ilk mektebi olan Lisan Mektebi'nin açılış süreci incelendiğinde (Yıldırım, 2010, s. 47), konuyla ilgili ilk girişimin dönemin Maarif Nazırı olan Ahmed Kemal Efendi tarafından başlatıldığı görülmektedir. Kemal Efendi'nin kaleme alarak Hükümet'e sunduğu ayrıntılı tezkere, günün intiyaçlarından doğan yeni bir dil okulu projesi olarak değerlendirilebilir. 17 Mart 1866 tarihli bu tezkerede, açılmasını önerdiği Lisan Mektebinin gerekliliği, amaç ve işlevini adım adım anlatmıştır. Öncelikle, 1860'larda Tercüme Odasının işlevinin azalmasıyla birlikte yabancı dil öğrenmek isteyenlerin Beyoğlu ve Galata'da bulunan gayrimüslim mekteplerine yönelmelerinden ötürü, doğrudan devlet yönetiminde bir dil mektebi açılması gerektiğine dikkat çekmiştir. Akabinde bu mektebin açılması için gerekli eğitim planlaması ve altyapı çalışmaları kapsamında bina, bütçe, mali kaynak, personel ve öğrenci temini gibi hususları açıklığa kavuşturmuştur (BOA. İ.DH. 547/38078, 1). Kemal Efendi'nin söz konusu tezkeresi için padişahlık makamınca verilen 26 Mart 1866 tarihli onaydan kısa bir süre sonra Lisan Mektebi, Mahrec-i Aklâm bünyesinde eğitim öğretim faaliyetine başlamıştır (BOA. I.DH. $547 / 38078,2)$.

Bu dönemde yeni okul türünün kuruluşuna yönelik bir diğer çalışma ise Mülkiye Mühendis ve Islah-ı Sanayi Mektebi üzerinedir. 1866 yılında pragmatist bir yaklaşımla politika geliştirilerek yol, köprü, maden ve orman işlerinde görevlendirilecek mühendislerin yetiştirileceği daha az masraflı yeni bir proje geliştirilmiştir. Maarif-i Umumiye Nazırı Kemal Efendi'nin de aralarında bulunduğu Hükümet üyelerinden oluşan bir komisyonun hazırladığı söz konusu proje padişahlık makamınca kabul görmüştür. Böylelikle Mülkiye Mühendis ve Islah-ı Sanayi Mektebinin kuruluşu karara bağlanmıştır. Her ne kadar bu kararın uygulamaya geçirilmesi noktasında sorunlar yaşanmış olsa da Sanayi Mektebinin kuruluşuna yönelik olarak geliştirilen politikalarda Kemal Efendi, Maarif Nazırı olarak Hükümet üyeleri arasındaki yerini almış; hem kendinin hem de başında bulunduğu Maarif Nezaretinin üstüne düşen sorumluluk ve görevleri yeri geldikçe üstlenmiştir.

Bu dönemde yönetim politikaları kapsamındaki en önemli gelişme ise Maarif Nazırı Kemal Efendi'nin resmi bir görevlendirme nedeniyle Belçika ve Fransa seyahatine çıkması ve bu seyahatinde yabancı temsilcilerle Osmanlı maarifi üzerine önemli görüşmeler gerçekleştirmesidir. Özellikle de 1866 yılı Mayıs ayında Fransa Eğitim Bakanı Jean Victor Duruy ile Paris’te yaptığı görüşme ve Paris'teki temel eğitim kurumlarını ziyaret etmesi oldukça önemlidir (The Dundee Courier And Argus, 30 Mayıs 1866, s. 3). Nitekim büyük ölçüde Fransız eğitim sisteminin etkisi ve Fransa devlet ileri gelenlerinin yönlendirmeleriyle 1868'de Mekteb-i Sultaninin kurulması ve 1869 'da Maarif-i Umumiye Nizamnamesinin yayımlanması öncesinde gerçekleşen Kemal Efendi'nin bu seyahati oldukça manidardır (Hasebe, 2018, s. 193). Ahmed Kemal Efendi'nin gerek söz konusu ziyareti gerek Avrupa ile ilişkiler bağlamındaki diğer çalışmaları nedeniyle Tanzimat Dönemi Osmanlı maarifinin kaderinin şekillenmesinde belirleyici bir şahsiyet olarak öne çıktığı ileri sürülebilir.

Belirtilen yönetim politikalarına uygun bir şekilde bu dönemde eğitim ekonomisi alanını ilgilendiren politikalar da geliştirilmiş ve bu doğrultuda uygulamalara girişilmiştir. Yeni açılan veya daha önce açılmış okullara atanan çok sayıda öğretmen için maaş tahsisatı gerçekleştirilmiştir. Bunun yanı sıra hem merkez hem de taşradaki çok sayıda okulun ders araç gereçlerinin temini (BOA. A.MKT.MHM. 350/24, 4-1; BOA. A.MKT.MHM. 339/29) ve diğer fiziki ihtiyaçlarının karşılanması için gerekli bütçe düzenlemeleri yapılmıştır (BOA. I..MVL. 503/22764; Akt: Yıldırım, 2010, s. 35; BOA. A.MKT.MHM. 341/84; BOA. A.MKT.MHM. 351/78; BOA. i.HR. 219/12688, 12-1; BOA. i.DH. 542/37713).

Diğer politikaların yanı sıra eser basım ve yayımına ilişkin politikalar özellikle dikkat çekicidir. Bu dönemde Maarif Nezaretine bağlı olarak yürütülen eser basım ve faaliyetlerine ilişkin gelişmeler üç grupta ifade edilebilir. Bunlardan ilki ülkedeki kimi şahıslara eser basımı için ruhsat verilmesi (BOA. A.MKT.MHM. 337/91; BOA. A.MKT.MHM. 344/44; BOA. A.MKT.MHM. 350/82, BOA. MVL 1033/28; BOA. I. MVL. 554/24887; BOA. I.DH. 553/38513; BOA. A.MKT.MHM. 362/71; BOA. İ. DH. 592/41225; BOA. A.MKT.MHM. 381/50), ikincisi özel matbaa kurmaya yönelik girişimlere izin verilmesi (BOA. HR.iD. 1456/57; BOA. A.MKT.MHM. 375/16) ve üçüncüsü basım ve yayım yasaklamalarıdır (Ali Suavi, 13, Mayıs 1945, s. 403; İskit, 1943, s. 24). Bu dönemde İstanbul'da pek çok telif ve tercüme eserin basımına ruhsat verildiği, okulların modern ders kitabı ihtiyacının giderilmesi için devlet matbaasında bazı

| Kastamonu Eğitim Dergisi, 2020, Vol. 28, No. 6| 
eserlerin basıldığı ve Suriye Vilayetinde özel bir gazete çıkarılmasına izin verildiği görülmektedir. Bazı özel müteşebbislere matbaa kurma izni verildiği gibi kimi gazetelerin de Matbuat Nizamnamesi hükmünce kapatıldığını görmek mümkündür. Dolayısıyla bir yanda eğitim ve kültür hayatı için önemli gelişmeler yaşanırken diğer yanda devlet denetiminin belirginleşerek her alanda kendini göstermeye çalıştığı anlaşılmaktadır.

Bu dönemin en önemli eğitim ve kültür uygulamalarından biri Tercüme Cemiyeti'nin kuruluşudur. 1850'li yıllardan itibaren Batı'dan tercüme eserler yoluyla bilimsel ve kültürel ögelerin Osmanlı'ya intikali görevini üstlenen Encümen-i Danişin 1860'lı yıllarda etkisini yitirmesinin ardından Ahmed Kemal Efendi'nin Maarif Nazırı olarak görev yaptığı 1865 yılında Maarif Nezareti çatısı altında bir Tercüme Cemiyeti kurulmuştur (BOA. İ. MVL. 529/23733, 4-1, 5-1). Kemal Efendi ve dönemin diğer devlet adamlarının çabalarıyla kurulan bu cemiyet, Tanzimat modernleşmesi bağlamında daha da netleşen Osmanlı Batılılaşmasının yolunu tam olarak netleştirdiği, devlet adamlarının modern paradigmayı Batı'dan alma yolunda önceye nazaran daha belirgin ve net politikalara giriştiğinin bir delili olabilir. Ahmed Kemal Efendi özelinde düşünüldüğünde ise Tercüme Cemiyetinin kuruluşunda oynağı rol, onun modernist ve reformist Tanzimat bürokratı özelliklerinin açık göstergesi olarak kabul edilebilir.

\section{Şura-yı Devlet Maarif Dairesi Başkanlığı Dönemi (1868-1870)}

Osmanlı Devleti'nde karar alma ve politika üretme organı olarak faaliyet gösteren Meclis-i Vala-yı Ahkam-ı Adliyenin yerine 5 Mart 1868 tarihli bir iradeyle Şura-yı Devlet kurulmuştur. Beş daireden oluşan Şûrâ-yı Devletin Maarif Dairesinin amacı, ülkede eğitimin yaygınlaştırılması gayesiyle mektep ve medreselerle ilgili uygulamalar hakkında politika üretmek ve maarifle ilgili idari davalara bakmaktır (Çora, 2008, s. 92). Maarif Dairesinin kuruluşuyla birlikte bu dairenin başkanlığına Ahmed Kemal Efendi atanmıştır. Dolayısıyla Kemal Efendi, bu görevdeyken artık Maarif Nezareti bünyesinde politikalar geliştirilmesinden daha öte bir görevi icra etmiş, ülkede maarifle ilgili en üst kademede politika üreten bir birimin başında yer almıştır.

Kemal Efendi bu görevde bulunduğu sırada başta 1869 Maarif-i Umumiye Nizamnamesi olmak üzere Osmanlı eğitim reformlarının yasal bir zemine oturtulması noktasında geliştirilen pek çok metnin altına imza atmıştır (Ahmed Lütfi, 1989, s. 9-13). Bu çerçevede 5 Mart 1868 tarihinden itibaren Evkaf-ı Hümâyun Nazırlığına atandığı 25 Ekim 1870 tarihine kadarki süreçte, Kemal Efendi'nin Şura-yı Devlet Maarif Dairesi Başkanlığında alınan kararlar ve üretilen politikalar genel olarak değerlendirildiğinde; yönetim politikaları, müfredat politikaları, eğitim personeli yetiştirme politikaları, eser basım ve yayım faaliyetlerine ilişkin alanlarda politikalar geliştirildiği görülmektedir. Bunlar arasında en dikkat çekici olanının ise Maarif-i Umumiye Nizamnamesinin yayımlanması olduğu ileri sürülebilir (BOA. İ. MMS, 37/1541; BOA. ŞD. Defter no: 234; Düstur H.1289/M. 1872-1873, s. 184-219; Bilim, 2002, s. 437-474). Osmanlı-Avrupa devletleri arasındaki eğitsel etkileşimler sonucunda ortaya çıkan ve Nizamnamenin özellikle Fransız eğitim politikalarından derin izler taşıyan bu Nizamname ile hem Osmanlı maarif hayatında önemli bir düzenleme yapılmış hem de daha sonraki eğitim uygulamaları belli bir plan ve sistematiğe büründürülmüştür. Bununla birlikte Osmanlı maarifinin hemen tüm alanlarında politikalar geliştirildiği/belirlendiği görülmektedir. Ayrıca söz konusu politikaların daha sonraki dönemlere de örnek teşkil ettiği ve Cumhuriyet Dönemi de dâhil olmak üzere Türk eğitim politikalarına temel oluşturduğu söylenebilir.

Kemal Efendi'nin Maarif Dairesi Başkanlığı dönemine ilişkin arşiv belgelerine yansıyan daha pek çok konu görmek mümkündür. Bu çerçevede öğretmen ihtiyacının karşılanmasına yönelik uygulamalar kapsamında Darülmuallimînden diploma alarak mezun olan öğretmen adaylarından tayin edildikleri yerlere gitmeleri konusunda taahhütname alınması usulü getirilmiştir (BOA. IşD. 10/488). Yeni okul açılışına yönelik uygulamalar kapsamında Saraybosna'da Hristiyan kadınlar için açılan dikiş ve nakış mektebine özel bütçe tahsisatı yapılmıştır (BOA. İ.ŞD. 6/304). Ekonomi politikaları dâhilinde değerlendirilebilecek bu uygulamaya ek olarak mektep inşa masraflarının karşılanmasına yönelik uygulamalara da rastlanmaktadır (BOA. i.şD. 8/430). Müfredat politikaları kapsamında ise taşrada bulunan Müslümanların öğrenim gördüğü rüştiye mektepleri programlarına Fransızca dersinin konulması yönünde bir girişimde bulunulmuştur (BOA. I.ŞD. 9/446).

\section{Üçüncü Maarif Nazırlığı Dönemi (1871-1872)}

Ahmed Kemal Paşa, 5 Ekim 1871 tarihinde Maarif Nazırlığı görevine tayin edilmiştir (BOA. I.DH. 639/44434; BOA. MB.i.25/40). Ancak bu görevi çok uzun sürmemiş olup 5 Ocak 1872 tarihinde Şura-yı Devlet üyeliğine yeniden atanınca sona ermiştir. Dolayısıyla üç ay süreyle sürdürdüğü bu nazırlık döneminde ilişkin Nezaret bünyesinde gerçekleştirilen bir faaliyete ulaşılamamıştır. Bir açıdan bakıldığında, bu nazırlık döneminde Kemal Paşa'nın görev süresi her ne kadar kısa da olsa Nezaret bünyesinde birtakım rutin eğitim yönetimi uygulamalarının sürdürüldüğü ve belirli ölçülerde icraatta bulunulduğu düşünülebilir. En azından bu dönemde, yayımlanmasının ardından birkaç yıl geçmiş olan Maarif-i Umumiye Nizamnamesini uygulamaya yönelik olarak çeşitli girişimlerde bulunulmuş olması kuvvetle muhtemeldir. Ne var ki araştırma sürecinde incelemeye alınan veri kaynağı gruplarından bu doğrultuda bilgi sağlanamamıştır. Bu durum ise veri kaynaklarının bir sınırlılı̆ı olarak değerlendirilebilir.

\section{Dördüncü Maarif Nazırlığı Dönemi (1872-1873)}

Ahmed Kemal Paşa, Şura-yı Devlet Üyeliği görevindeyken maarif alanında bilinen ve güvenilen bir beceri ile donanıma sahip olduğunun altı çizilerek 5 Aralık 1872 tarihinde Maarif Nazırlığına dördüncü kez atanmıştır (BOA. I.DH. 659/45890). Bu atamadan dolayı Maarif Nezareti personelinin büyük memnuniyet duyduğu, atama haberinin ardından Nezaret personeli tarafından padişahlık makamına hitaben kaleme alınan teşekkür mektubundan anlaşılmaktadır. Söz konusu mektupta; Kemal Paşa'nın daha 
önceki görevlerinde Osmanlı maarifinin gelişimi için büyük katkıları olduğundan bahisle yeni atandığı bu Maarif Nazırlığı görevinde de şüphesiz aynı çabayı göstereceğine inanıldığına vurgu yapılmış ve bu durumun Nezaret personeli olarak görevlerini en iyi şekilde yerine getirebilmeleri için kendilerine büyük bir motivasyon kaynağı olduğu belirtilmiştir (BOA. i..DH. 659/45916). Hem kendisi hem de birlikte çalıştığı nezaret personeli için pek olumlu görünen bu atmosfer altında 5 Aralık 1872'de görevine başlayan Kemal Paşa, 23 Nisan 1873'e kadar Nazırlık görevini sürdürmüştür.

Kemal Paşa'nın yaklaşık beş ay kadar süren bu nazırlık dönemi genel olarak incelendiğinde; yönetim politikaları, ekonomi politikaları, müfredat politikaları, fırsat eşitliğinin sağlanmasına ilişkin politikalar, okullaşma politikaları, öğretmen yetiştirme ve geliştirme politikaları ve eser basım ve yayım faaliyetlerine ilişkin alanlarda politika üretildiği anlaşımaktadır. Yönetim politikaları çerçevesinde daha önceki dönemlerde de görüldüğü üzere bilhassa rüştiye mekteplerine eğitim personeli ihtiyacının karşılandığı, ilk defa Darülmuallimat mezunu kadın öğretmenlerin atamalarının yapıldı̆̆ı, rüştiye mekteplerinin ülke çapında yaygınlaştırılması faaliyetlerine hız kesmeden devam edildiği görülmektedir. Dikkat çeken bir nokta ise Nezaret bünyesinde yönetim ve organizasyonel uygulamalar hakkında veriye ulaşılamamış olmasıdır. Ancak bu durum 1869 Maarif-i Umumiye Nizamnamesinin bağlamında düşünüldüğünde, Nezaretin yönetim ve işleyiş süreçlerine dair zaten en temel düzenlemelerin bu nizamnameyle yapılmış olduğu ve bu dönemde olsa olsa söz konusu düzenlemelerin hayata geçirilmesine yönelik bir çaba sarf edildiği akla gelmektedir. Yönetim politikalarının yanı sıra eğitim ekonomisi alanına giren birtakım uygulamalara da rastlandığı okul bütçelerinde kısıtlamaya gidildiği, öğretmen maaşlarının daha önceki dönemlere nazaran düşürüldüğü, ders araç gereçlerinin temini ve dağıtımı için ek harcamalar yapıldığı görülmektedir. Dönemin politikaları arasında en dikkat çekici husus ise ülkedeki eser basım ve yayım faaliyetlerine ilişkin Maarif Nezareti bünyesinde merkezi bir kontrol mekanizması kurulmuş olmasıdır. Bir anlamda halkın bilinçlendirilmesine yönelik "informal eğitim" kapsamında da değerlendirilebilecek olan Tanzimat Dönemi kitap basım ve üretim faaliyetlerinin devlet gözetiminde sürdürülmesine üst düzeyde önem verilmiştir. Böylelikle devlet, bir yandan kendi kurduğu okullarda belirli bir siyasi ve ideolojik kontrol altında örgün eğitimi sürdürürken diğer yandan basım yayım faaliyetlerinin gelişmesi neticesinde kendiliğinden ortaya çıkan söz konusu informal eğitimi de kontrol altına almaya çabalamıştır. Kitap basmak ve matbaa kurmak için özellikle 1864 yılında yayımlanan Matbaalar Nizamnamesindeki düzenlemelerin bu dönemde etkin bir şekilde uygulanmaya çalışıldığı ve böylelikle devlet tarafından Tanzimat Dönemi entelektüel hayatını bilinçli bir şekilde gözetim altında tutulmaya çalışıldığı ileri sürülebilir. Ne var ki bu çabalar bir yandan sosyo-kültürel hayatı kısıtlayan bir etki yaratmış olsa da "bilginin paylaşımı ve yayılması"na engel olunamamıştır. Nispeten II. Abdülhamid döneminde (1876-1908) etkisini daha da hissettiren entelektüel hayattaki gözetim ve sosyal hayattaki kontrol mekanizması bile nihayetinde, bilginin mesafe ve engel tanımazlığına yenik düşmüştür.

Doğal olarak birbiriyle bağlantılı olan bu dönemdeki politika alanları bütüncül bir eksende değerlendirildiğinde; Kemal Paşa'nın bu nazırlık döneminde ülke çapında halkın (sivil) eğitiminin sağlanmasına yönelik olarak modern politikalar geliştirildiği ve uygulamalarda bulunulduğu ileri sürülebilir. Bu durum özellikle Osmanlı eğitim sistemini her yönüyle kucaklayarak sistematik ve merkezi bir düzene bağlamaya çalışan 1869 Maarif-i Umumiye Nizamnamesi ile birlikte düşünüldüğünde; eğitimde modernleşme kapsamında merkezileşmeye oldukça önem verildiği, yönetici elitin siyasi bir arzusu olarak sosyal kontrolün sağlanması için eğitimin işlevsel bir araç olarak kullanılması politikasının etkin bir biçimde sürdürüldüğü görülmektedir.

\section{Beşinci Maarif Nazırlığı Dönemi (1876)}

Maarif Nazırı Ahmed Cevdet Paşa'nın Suriye valiliğine atanmasından dolayı Maarif Nazırlığı görevi, o sırada Evkaf Nazırı olan Ahmed Kemal Paşa'ya verilmiştir. Ancak kısa bir süre sonra Ahmed Cevdet Paşa'nın Suriye görevi için hemen yola çıkmayacağı anlaşılarak Maarif Nazırlığı görevi Kemal Paşa'dan alınarak tekrar Cevdet Paşa'ya verilmiştir (Inal ve Yaşar, 1984, s. 56; İnal, 1925, s. 40-54; Mehmed Atıf, 2016). Dolayısıyla Maarif-i Umumiye Nazırlığına beşinci kez atanan Ahmed Kemal Paşa, 7 Mayıs $1876-16$ Mayıs 1876 tarihleri arasında bu görevini sürdürmüştür (BOA. ŞD.880/57). Incelenen arşiv belgelerinden hareketle bu kısa süreçte, Maarif Nezaretinin eğitim politika ve uygulamalarına yansıyan herhangi bir konu tespit edilememiştir.

\section{Altıncı Maarif Nazırlığı Dönemi (1877-1878)}

Ahmed Kemal Paşa, Evkaf Nazırlığı görevini sürdürdüğü sırada, 10 Aralık 1877 tarihinde (altıncı kez) ilave memuriyetle Maarif Nazırlığı görevine atanmıştır (BOA. ŞD.880/57). 11 Ocak 1878 tarihinde Meclis-i Ayan Üyeliğine atanıncaya kadar yaklaşık bir ay bu görevi sürdürmüştür (BOA. Y.EE. 75/19; Pakalın, 1940, s. 6).

Bu dönemde yönetim politikaları, ekonomi politikaları, denetim politikaları, müfredat politikaları, nitelik geliştirme politikaları, okullaşma politikaları, okul düzeyinde politikalar, eğitim personeli yetiştirme ve geliştirme politikaları ile eğitim planlamasına ilişkin politikalar geliştirildiği ve belirli ölçülerde uygulandığı anlaşılmaktadır. Eğitim yönetimi alanındaki diğer üst düzey görevleriyle mukayese edildiğinde bu dönemdeki politikaların nicelik olarak azlığı ve kapsadığı politika türü olarak sınırıı̆̆ı göze çarpmaktadır. Bu dönemde özellikle Ayıntap şehrinde bir Protestan okulu kurulması için gerekli iznin verilmesi (BOA. MF.MKT. 52/111), yabancı okulların Osmanlı'da günden güne yayılma göstermesiyle ilişkilendirilebilir. Öyle ki bu dönemde sonra yabancı okulların önü hiç alınamamış; yöneticiler belirli önlemler almaya teşebbüs etmişlerse de bu okulların Osmanlı için bilhassa zarar getiren uygulamaları Cumhuriyet Dönemine kadar devam etmiştir. Ancak bu dönemdeki en yaygın politika faaliyetinin ve asıl odak noktasının rüştiye mektepleri olduğu açıkça görülmektedir. Nitekim yeni rüştiye mekteplerinin açılması ve bu mekteplere gerekli ders araç gereçlerinin teminine yönelik uygulama örnekleri bulunmaktadır. Bunun yanı sıra rüştiyelere öğretmen atamaları ve öğretmenlerin nakil, becayiş, maaş, izin durumlarıyla birtakım disiplin sorunlarına çözüm bulmaya yönelik uygulamalar gibi Nezaret bünyesinde

| Kastamonu Eğitim Dergisi, 2020, Vol. 28, No. 6| 
birtakım önemli faaliyetler gerçekleştirilmiştir (BOA. MF.MKT. 51/198; 51/214; 52/74; 52/28; 52/82; 52/104; 52/99; 52/119; 52/135; BOA. MF.iBT. 12/7; 12/9; 12/17). Genel olarak bakıldığında söz konusu uygulamaların taşrada rüştiye mekteplerinin yaygınlaştırılmasına ve merkezi bir düzen oluşturarak eğitim yönetiminin modern bir yaklaşımla yapılandırılmasına hizmet ettiği anlaşılmaktadır. Buradan hareketle Kemal Paşa'nın bu nazırlık döneminde de devletin eğitimde modernleşme sürecinde temel politika olarak gördüğü halkın devlet karşı itaatinin sağlanması ve Osmanlıcılık ideolojisi ekseninde sosyal disiplinizasyonun sağlanması bağlamında önemli gelişmeler kaydedildiği ileri sürülebilir.

\section{SONUÇ VE DEĞERLENDIRMELER}

1847-1876 yılları arasındaki Osmanlı eğitim modernleşmesi sürecinin önde gelen aktörlerinden biri olan Ahmed Kemal Paşa'nın eğitim alanındaki politika ve uygulamalarının irdelendiği bu araştırmadan elde edilen bulgular sonucunda pek çok özgün bilgi ve belgeye dayanarak birtakım yorumlamalara gidilmiş ve zatıâlinin Osmanlı eğitim modernleşmesinde öncü bir role sahip olduğu müşahede edilmiştir. İlk olarak 1847 yılında Mekatib-i Umumiye Muavinliğiyle başlayan ve daha sonra Maarif-i Umumiye Nazırlığı, Şura-yı Devlet Maarif Dairesi Başkanlığı ve farklı tarihlerde altı kez atanmış olduğu Maarif Nazırlığı görevleriyle devam eden Kemal Paşa'nın eğitim yöneticiliği görevleri Tanzimat dönemi Osmanlı eğitiminin modernleşmesi bağlamında oldukça önemlidir. Kemal Paşa'nın, Tanzimat Döneminin reformist ve aydın bürokratlarından biri olarak özellikle Osmanlı eğitim modernleşmesi sürecinde yön tayin edici, belirleyici ve öncü bir hizmette bulunmuş bir eğitimci olduğu söylenebilir. Hem teorisyen hem de (daha çok ön plana çıkan) pratisyen rolleriyle bu sürecin başkahramanlarından biri olduğu anlaşılan Kemal Paşa'nın, eğitim modernleşmesine uzun yıllar hizmette bulunmuş ve bu uğurda ömür harcamış biri olduğunun altı çizilebilir.

Kemal Paşa'nın Mekatib-i Umumiye Muavinliği ve Nazırlığını görevlerini sürdürdüğü 1847-1854 yılları arasında, rüştiye mekteplerinin kurulması ve hem merkezde hem de taşrada yaygınlaştırılması için önemli faaliyetler gerçekleştirilmiştir. Bu dönemde belirlenen politika ve gerçekleştirilen uygulamaların daha gelişmiş uzantılarını, Kemal Efendi'nin 1860'lı yıllarda başlayan nazırlık dönemlerinde görmek mümkündür. Bir "halk eğitimi hareketi” olarak açılan rüştiye mekteplerinin, Osmanlı’dan Türkiye Cumhuriyeti'ne intikal eden modern kimlikli bireylerin gelişmesi, Osmanlı'nın merkezileşmesi ve merkezi değerlerin çevrede yaygınlaşması (Gündüz, 2016, s. 216) süreci için oldukça büyük bir temel oluşturduğu söylenebilir. Daha vurgulu bir ifadeyle rüştiye mektepleri aracılı̆̆ıla devlete karşı siyasi sadakat bağları güçlü bireyler yetiştirmek ve islami duyguları güçlendirmek Tanzimat Dönemi eğitim reformunda bilhassa "çevre nüfus gruplarına yönelik eğitim politikası"nın temel hedefi olmuştur (Somel, 2015, s. 31). Bu vesileyle geleneksel paradigmanın ötesinde, modern eğitim paradigmasıyla amaca uygun bir şekilde yeniden yapılandırılan eğitim-iktidar, birey-devlet ilişkileri sonraki dönemlere de örnek oluşturan bir sistem haline dönüşmüştür.

Kemal Paşa'nın, 1850'li ve 1860'lı yıllarda Avrupa'daki okullarda uygulanan eğitim sistemini yerinde gözlemleyerek incelemelerde bulunmuş olması, Osmanlı eğitim reformlarına modern bir bakış açısı kazandırılması bakımından oldukça önemlidir. Bu doğrultuda, Kemal Efendi, modernitenin Osmanlı eğitimine girişi için ilk uygulamalara öncülük etmekle kalmamış; bununla birlikte daha sonraki süreçlerde eğitim alanında atanmış olduğu üst düzey yöneticiliklerde, söz konusu eğitim reformlarının belli bir düzene oturtularak kalıcı politikalara dönüşmesi için de uğraşmıştır. Dolayısıyla Ahmed Kemal Paşa'nın Avrupa eğitim sistemine ilişkin gerçekleştirdiği incelemelerin Osmanlı eğitim sistemine etkisi, tarihsel bir olgu olarak sonraki dönemlerde de devam etmiştir.

Ahmed Kemal Paşa'nın eğitim yöneticiliği dönemlerinde ilk, orta ve lise düzeyindeki okullara ek olarak bilhassa 1866-1867 yıllarında dil okulu, mesleki okullar, sanayi mektebi, tıbbiye vb. pek çok farklı okul türünün açıldığı görülmektedir. Tanzimat Fermanı'nın (1839) ilan edilmesinden 1867 yılına kadar geçen süre içerisinde modern okulların yaygınlaştırılması suretiyle bu okullarda yetişen bireylerin sayısı artırılmıştır. Nicelik yönünden sağlanan bu olgunlaşma, niteliksel gelişimi de beraberinde getirmiştir. Bunun doğal bir sonucu olarak temel eğitim dışında yüksekokullar ile teknik ve meslek okullarının açılması ve bu okulların etki alanlarının genişletilmesi çalışmalarına hız verilmiştir. Bu başarı ise hiç kuşkusuz Ahmed Kemal Paşa'nın modern usullerde eğitim veren rüştiye mektepleri ve buradan mezun olanların sayısının artırılması politikasının eseridir. Ayrıca giderek merkeziyetçi bir yapı kazandırılan "eğitim unsuru" nun ülke sathında yayılmasına yönelik çabaların ve edinilen tecrübelerin daha sonraki dönemlere örnek oluşturması pek tabiidir. Bu doğrultuda özellikle II. Abdülhamid Dönemi’nde (1876-1908) hızlı bir ivme kazanan maarifin yaygınlaştırıması politikasının devlet ideolojisine uygun şekilde bir Osmanlı toplumu yaratılması ve toplumun sosyal disiplin ve kontrolünün sağlanması politikalarına temel oluşturduğu söylenebilir.

Lisan Mektebi projesinin Hükümete sunulması, projenin hayata geçirilmesi ve sonrasında devlet dairelerinin yabancı dil bilen bürokrat intiyacını giderme noktasındaki nisbî başarısının doğrudan Kemal Efendi’ye ait olduğu göz önüne alındığında; onun bürokrat profilindeki yenilikçi ve pragmatist özelliklere sahip bir eylem adamı olduğu çıkarımına rahatlıkla varılabilir. Ayrıca Kemal Efendi'nin, çeşitli komisyonlarda üstlendiği üyelik görevleri onun bürokratik işlerde çözüm odaklı hareket edebilme, mevcut şartlar altında duruma uygun çözümler üretebilme, uygulama sürecinin karar alma ve politika belirleme süreçlerinden daha özel koşullar içerdiğini görebilme gibi konularda beceri ve tecrübe kazanmasını sağladığı ileri sürülebilir. Ayrıca söz konusu durum, onun çok yönlü devlet adamı profilini de destekler mahiyettedir.

Modern paradigmaya uygun olarak telif edilen eserlerin yanı sıra Batı'daki aydınlanma çağının ürünü olan kimi eserlerin çeviri yoluyla Osmanlı eğitim ve kültür hayatına kazandırılmış olması, Tanzimat Dönemi'nin aydın ve bürokrat çevresinin sahip olduğu modern zihniyetin şekillenmesine önemli ölçüde etki etmiştir. Bazı eserlerin doğrudan mekteplerde okutulmak üzere yayımlanmış olduğu dikkate alındığında bu etkinin hem tavanda hem tabanda kendini göstermesi amaçlanmıştır. Ahmed Kemal Paşa'nın eğitim yöneticiliği dönemlerinin eser basım ve yayımı açısından canlı birer dönem olduğu, bu canlılı̆ın Tanzimat modernleşmesinin bir sonucu olarak ortaya çıkmakla birlikte modern paradigmanın devlet ve toplum nezdinde şekillenerek yer bulmasında etkili olduğu 
ileri sürülebilir. Ayrıca bu durum, entelektüel yaşamın en önemli yanını oluşturan gazete, kitap türünden eserlerin basım ve yayımının, toplumu nasıl şekillendirebileceği konusunda farkındalığın oluştuğunu göstermektedir. Böylelikle Osmanlı yönetici elitinin artık bu bilinçle hareket ederek merkezi bir sistem altında Osmanlı halklarının sosyal kontrolünü sağlamaya ve bununla birlikte basım-yayım hayatında Osmanlııı ideolojisine aykırı şekilde oluşabilecek uygulamaların önüne geçmek için denetlenebilirliği sağlayan bir mekanizma kurmaya çalıştığı ileri sürülebilir.

\section{KAYNAKÇA}

Ahmed Kemal, (H. 1262 / M. 1846). Farisî Tekellüm Risalesi. İstanbul: Tabhane-i Âmire Taş Destgâhı.

Ahmed Lütfi, (1989). Vak'a-nüvis Ahmed Lûtfî Efendi Tarihi. (Cilt 12), (Haz.) M. Münir Aktepe, Ankara: Türk Tarih Kurumu.

Aksu, A. (2008). İngiltere-Amerika-Osmanlı hattında Lancaster öğretim sistemi. Değerler Eğitimi Dergisi, 6(16), 29-67, Erişim adresi: https://dergipark.org.tr/tr/pub/ded/issue/29184/312500 (20.04.2020).

Akyıldız, A. (2012). Osmanlı bürokrasisi ve modernleşme. (4. Baskı). İstanbul: İletişim.

Akyıldız, A. (2016). Mekteb-i Maarif-i Adliye. İs/âm Ansiklopedisi. (Cilt EK-2), 238-240, İstanbul: Türkiye Diyanet Vakfı. Erişim adresi: https://islamansiklopedisi.org.tr/mekteb-i-maarif-i-adliyye (29.12.2019).

Akyüz, Y. (1994). İlkögretimin yenileşme tarihinde bir adım: Nisan 1847 Talimatı. Ankara Üniversitesi Osmanlı Tarihi Araştırma ve Uygulama Merkezi Dergisi (OTAM) 5(5), 1-47. Erişim adresi: https://www.kisa.link/NcmJ (11.04.2020).

Akyüz, Y. (2006). Türkiye'de öğretmen yetiştirmenin 160. yılında Darülmuallimîn'in ilk yıllarına toplu ve yeni bir bakış. Ankara Üniversitesi Osmanlı Tarihi Araştırma ve Uygulama Merkezi Dergisi (OTAM), 20(20), 17-58.

Ali Suavi, (Mayıs 1945). Başlıksız. Aylık Ansiklopedi. (13). Taha Toros Arşivi, Dosya No: 266, internet erişim: http://earsiv.sehir.edu.tr:8080/xmlui/handle/11498/15428

Altınova, A. (2010). Osmanlı modernleşmesinde rüştiye mektepleri. Yayımlanmamış Doktora Tezi. Gazi Üniversitesi, Ankara.

Berker, A. (1945). Türkiye'de ilköğretim (1839-1908). Ankara: Millî Eğitim Basımevi.

Bilim, C. Y. (2002). Türkiye'de çağdaş eğitim tarihi (1734-1876). (Genişletilmiş 2. Baskı). Eskişehir: Anadolu Üniversitesi.

Binbaşığlu, C. (1996). Illk ilkokul yönetmeliği (Nisan 1847 Talimatı) üzerine bir inceleme eseri. Çağdaş Eğitim 21(223), 7-10.

BOA (T.C. Cumhurbaşkanlığı Devlet Arşivleri Başkanlığı Osmanlı Arşivleri), A.AMD. (Bâb-ı Âsafî Âmedî Kalemi), 26/23, (H. 26 Muharrem 1267 / M. 1 Aralık 1850); 32/78, (H. 29 Zilhicce 1267/M. 25 Ekim 1851); 32/5, (H. 17 Zilhicce 1267 / M. 13 Ekim 1851); 36/89, 1-1, (H. 6 Cemaziyelahir 1268/M. 28 Mart 1852).

BOA, A.DVN. (Bâb-ı Âsafî Divan-ı Hümâyûn Kalemi), 68/13, (H. 10 Cemaziyelahir 1267/M. 12 Nisan 1851).

BOA, A.DVN.MHM. (Bâb-ı Âsafî Divan-ı Hümâyûn Mühimme Kalemi), 34/88, (H. 23 Cemaziyelevvel 1278/M. 26 Kasım 1861); 35/87, (H. 20 Şaban 1278/M. 20 Şubat 1862).

BOA, A.M. (Sadâret Müteferrik), 9/33, (H. 7 Şevval 1267/M. 5 Ağustos 1851).

BOA, A.MKT. (Sadâret Mektubî Evrakı), 71/19, (H. 27 Rebiülevvel 1263/M. 15 Mart 1847); 91/52, (H. 8 Şaban 1263/M. 2 Temmuz 1847); 91/52, (H. 8 Şaban 1263/M. 2 Temmuz 1847).

BOA, A.MKT.MHM. (Sadâret Mektubî Mühimme Kalemi), 241/29, (H. 30 Rebiülevvel 1279 / M. 25 Eylül 1862); 31/46, (H. 8 Cemaziyelahir 1267/M. 10 Nisan 1851); 337/91, (H. 21 Safer 1282/M. 16 Temmuz 1865); 339/29, (H. 8 Rebiülevvel 1282/M. 1 Ağustos 1865); 344/44, (H. 3 Cemaziyelahir 1282/M. 24 Ekim 1865); 350/24, 4-1, (H. 19 Şevval 1282/M. 7 Mart 1866); 350/82, (H. 25 Şevval 1282 / M. 13 Mart 1866); 351/77, (H. 5 Zilkade 1282/M. 22 Mart 1866); 351/78 (H. 5 Zilkade 1282/M. 22 Mart 1866); 363/46, (H. 15 Cemaziyelevvel 1283 / M. 25 Eylül 1866); 373/57, (H. 24 Ramazan 1283/M. 30 Ocak 1867); 375/16, (H. 18 Şevval 1283/M. 23 Şubat 1867); 331/6, (H. 29 Zilkade 1281/M. 1 Mayıs 1865); 381/50, (H. 5 Muharrem 1284/M. 9 Mayıs 1867); 362/71, (H. 5 Cemaziyelevvel 1283/M. 15 Eylül 1866); 341/84, (H. 25 Rebiülahir 1282/M. 17 Eylül 1865).

BOA, A.MKT.MVL. (Sadâret Mektubî Kalemi Meclisi Vala Evrakı), 41/69, (H. 16 Receb 1267/M. 17 Mayıs 1851); 38/76, (H. 30 Rebiülevvel 1267/M. 2 Şubat 1851); 9/A.58, (H. 25 Şaban 1264/M.27 Temmuz 1848).

BOA, HR.iD. (Hariciye Nezâreti İdare), 1456/57, (H. 1 Rebiülahir 1282/M. 24 Ağustos 1865).

BOA, HR.TO. (Hariciye Nezâreti Hariciye Tercüme Odası), 407/9, (H. 12 Muharrem 1263/M. 31 Aralık 1846); 567/65, (H. 9 Şaban 1263 / M. 23 Temmuz 1847).

BOA, İ. MMS. (irâde Meclis-i Mahsûs), 37/1541, (H. 7 Rebiülevvel 1286/M. 17 Haziran 1869).

BOA, i.DH. (irâde Dahiliye), 134/6903, (H. 15 Muharrem 1263/M. 3 Ocak 1847); 135/6923, (H. 3 Muharrem 1263/M. 22 Aralık 1846); 155/8034, (H. 11 Şaban 1263/M. 25 Temmuz 1847); 162/8438, 3-1; 4-1, (H. 5 Muharrem 1264/M. 13 Aralık 1847); 162/8438, 4-1, (H. 5 Muharrem 1264/M. 13 Aralık 1847); 224/13324, (H. 23 Muharrem 1267/M. 28 Kasım 1850); 493/33436 (H. 23 Muharrem 1279 / M. 21 Temmuz 1862); 493/33491 (H. 16 safer 1279/M. 13 Ağustos 1862); 499/33912, (H. 24 Cemaziyelevvel 1279 / M. 18 Kasım 1862); 535/37188, (H. 28 Zilkade 1281 / M. 24 Nisan 1865); 542/37713, (H. 11 Cemaziyelahir 1282/M. 1 Kasım 1865); 547/38078, 1, (H. 29 Şevval 1282/R. 5 Mart 1282/M. 17 Mart 1866); 547/38078, 2, (H. 9 Zilkade 1282/M. 26 Mart 1866); 553/38513 (H. 29 Rebiülahir 1283/M. 10 Eylül 1866); 639/44434, (H. 20 Receb 1288/M. 5 Ekim 1871); 659/45890. (H. 4 Şevval 1289 / M. 5 Aralık 1872); 659/45916, (H. 11 Şevval 1289 / M. 12 Aralık 1872); 8034, (H. 11 Şaban 1263/M. 25 Temmuz 1847); 592/41225 (H. 14 Safer 1286/M. 26 Mayıs 1869); 617/42969, (H. 20 Cemaziyelevvel 1287 / M. 18 Ağustos 1870).

BOA, i.HR. (İâde Hariciye), 219/12688, 12-1, (H. 17 Zilkade 1282/M. 3 Nisan 1866). 
BOA, i.MVL. (îrâde Meclis-i Vâlâ), 529/23733, 4-1, (R. 15 Mart 1281/M. 27 Mart 1865); 529/23733, 5-1, (H. 16 Zilkade 1281/M. 12 Nisan 1865); 554/24887, (H. 28 Muharrem sene 1283/M. 12 Haziran 1866); 563/25280, (H. 22 Cemaziyelahir 1283/M. 1 Kasım 1866); 566/25432, (H. 4 Ramazan 1283/M. 10 Ocak 1867); 566/25480, (H. 11 Şevval 1283/M. 16 Şubat 1867); 567/25498, 1-1, (H. 8 ramazan 1283/R. 2 KanunI Sani 1282/M. 14 Ocak 1867); 532/23870, 2-1, (H. 29 Şevval 1281/M. 27 Mart 1865); 568/25545, (H. 19 Zilkade 1283/M. 25 Mart 1867); 570/25593, (H. 20 Zilkade 1283/M. 26 Mart 1867); 570/25622, (H. 2 Zilhicce 1283/M. 7 Nisan 1867); 571/25646 (H. 18 Zilhicce 1283/M. 23 Nisan 1867); 127/3324, (H. 24 Zilkade 1264/M. 22 Ekim 1848); 503/22764, (H. 13 Şevval 1280/M. 22 Mart 1864).

BOA, I.ŞD. (İrâde Şûrâ-yı Devlet), 6/304, (H. 10 Haziran 1284/M. 22 Haziran 1868); 8/430, (H. 9 Rebiülahir 1285/M. 30 Temmuz 1868); 9/446, (H. 4 Safer 1285/M. 27 Mayıs 1868); 10/488, (H. 6 Rebiülahir 1285/M. 27 Temmuz 1868).

BOA, MB.ì. (Mâbeyn-i Hümâyûn İrâdeleri), 20/153, (24 Nisan 1865/H. 28 Zilkade 1281); 25/40, (H. 20 Recep 1288/M. 5 Ekim 1871).

BOA, MF.iBT. (Maârif Nezâreti Tedrîsât-ı ibtidaiyye Kalemi), 12/7, (H. 6 Muharrem 1295/M. 10 Ocak 1878); 12/9, (H. 6 Muharrem 1295/M. 10 Ocak 1878); 12/17, (H. 6 Muharrem 1295/M. 10 Ocak 1878).

BOA, MF.MKT. (Maârif Nezâreti Mektubî Kalemi), 51/198, (H. 2 Zilhicce 1294/M. 8 Aralık 1877); 51/214, (H. 5 Zilhicce 1294/M. 11 Aralık 1877); 52/74, (H. 21 Zilhicce 1294 / M. 27 Aralık 1877); 52/28, (H. 12 Zilhicce 1294/M. 18 Aralık 1877); 52/82, (H. 21 Zilhicce 1294 / M. 27 Aralık 1877); 52/104, (H. 25 Zilhicce 1294/M. 31 Aralık 1877); 52/99, (H. 23 Zilhicce 1294/M. 29 Aralık 1877); 52/119, (H. 26 Zilhicce 1294/M. 1 Ocak 1878); 52/135, (H. 26 Zilhicce 1294/M. 1 Ocak 1878); 52/111, (H. 25 Zilhicce 1294 / M. 31 Aralık 1877).

BOA, MVL. (Meclis-i Vâlâ Meclis-i Vâlâ Evrakı), 1033/28, (H. 19 Muharrem 1283/M. 3 Haziran 1866); 954/41, (H. 26 Rebiülevvel 1279/M. 21 Eylül 1862).

BOA, Sadâret Mektubî Kalemi Nezâret ve Devair (A.MKT.NZD.), 384/56, (H. 10 Cemaziyelahir 1278/M. 14 Aralık 1861); 398/25, (H. 9 Şaban 1278/M. 9 Şubat 1862); 411/50, (H. 14 Şevval 1278/M. 14 Nisan 1862); 422/37, (H. 3 Zilhicce 1278/M. 1 Haziran 1862); 54/28, (H. 16 Recep 1268/M. 6 Mayıs 1852); 32/17, 1-1, (H. 12 Cemaziyelahir 1267/M. 14 Nisan 1851); 41/11, (21 Şevval 1267/19 Ağustos 1851).

BOA, Sadâret Mektubî Kalemi Umum Vilâyât (A.MKT.UM.), 559/60, (H. 29 Şevval 1278/M. 29 Nisan 1862); 539/94, (H. 11 Şaban 1278 / M. 11 Şubat 1862).

BOA, Şûrâ-yı Devlet (ŞD.), 880/57, (H. 2 Ramazan 1304/M. 25 Mayıs 1887); Defter no: 234 (H. 29 Ramazan 1285/M. 13 Ocak 1869).

BOA, Yıldız Esas Evrakı (Y.EE.), 75/19, (H. 7 Muharrem 1295/M. 11 Ocak 1878).

Cevdet Paşa, (1991). Tezâkir. (Yay. Haz.) Cavid Baysun. (3. Baskı). Ankara: Türk Tarih Kurumu Basımevi.

Çora, E. (2008). Osmanlı'dan Cumhuriyete Danıştay'ın gelişim süreci. Yayımlanmamış Doktora Tezi. İstanbul Üniversitesi Sosyal Bilimler Enstitüsü, istanbul.

Davud, F. (2017). Hâtimetü'I-Eş'âr (Fatîn Tezkiresi). (Haz.) Ömer ÇifÇi. Ankara: T.C. Kültür ve Turizm Bakanlığı Kütüphaneler ve Yayımlar Genel Müdürlüğü.

Demirel, M. (2009). Bezmiâlem Valide Sultan School: Darülmaârif. Middle Eastern Studies 45(3), 507-516.

Denzin, N. K. \& Lincoln, Y. S. (2005). Introduction: The Discipline and Practice of Qualitative Research. The Sage Handbook of Qualitative Research. (3 rd). (Ed.) N. K. Denzin ve Y. S. Lincoln. Thousands Oaks, CA: SAGE Publications, pp. 1-32.

Devlet Salnamesi (Salnâme-i Devlet-i Aliyye-i Osmaniyye), (H. 1269/M. 1853/1854); (H. 1270/M. 1854/1855); (H. 1271/M. 1855/1856). i̇stanbul: Darü't-Tıbaatü'l-Amire. İnternet erişim: http://isamveri.org/?url=salname (11.02.2019).

Duman, T. \& Dilaver, H. H. (1996). İstanbul'da açılan ilk Darülmuallimîn. Erdem, 9(26), 651-658, Erişim adresi: http://dergipark.org.tr/tr/pub/erdem/issue/44393/549343\#article_cite (19.04.2020).

Düstur (H.1289/M. 1872-1873). (1. Tertip, Cilt 2). İstanbul: Matbaa-yı Amire.

Engelhardt, E. P. (2017). Türkiye ve Tanzimat: Devlet-i Osmaniye'nin târih-i ıslahatı 1826'dan 1882'ye. (Çev.) Ali Reşad, (Yay. Haz.) Erol Kılınç. İstanbul: Ötüken Neşriyat.

Erdoğdu, A. T. (1995). Maarif-i Umumiye Nezareti teşkilatı: Idari teşkilat açısından. Yayımlanmamış Yüksek Lisans Tezi. İstanbul Üniversitesi Sosyal Bilimler Enstitüsü, İstanbul.

Erdoğdu, T. (1996). Maarif-i Umumiyye Nezareti teşkilatı I. Ankara Üniversitesi Siyasal Bilgiler Fakültesi Dergisi, 51(1), $183-265$.

Ergin, O. (1977). İstanbul mektepleri ve ilim, terbiye ve sanat müesseseleri -dolayısiyle- Türkiye maarif tarihi. (Cilt I-II), İstanbul: Eser Kültür.

Eyice, S. (1996). Fossati, Gaspare Trajano (1809-1883). İslâm Ansiklopedisi. (13), 170-173. İstanbul: Türkiye Diyanet Vakfı, Erişim adresi: https://islamansiklopedisi.org.tr/fossati-gaspare-trajano (13.05.2020).

Fatma Aliye, (1995). Ahmet Cevdet Paşa ve zamanı. İstanbul: Bedir.

Gündüz, M. (2016). Maariften eğitime: Tanzimat'tan Cumhuriyet'e eğitim düşüncesindeki dönüşüm. İstanbul: Doğu Batı.

Hasebe, K. (2018). The 1869 Ottoman public education act: Proceedings and participants. Osmanlı Araştırmaları, 51(51), 181-207. Doi: 10.18589/oa.591831.

İnal, i. M. K. (1925). “Hatıra-i Atıf”. Tarih-i Osmanî Encümeni Mecmuası, 15(7), 40-54. İstanbul.

İnal, i. M. K. (1969). Son asır Türk şairleri. (Cilt II.) İstanbul: Millî Eğitim Basımevi.

İnal, İ. M. K. \& Yaşar, H. H. (1984). Evkaf-ı Hümayun Nezaretinin kuruluş tarihi ve nazırların hal tercümeleri IV. (Sadeleştirerek Neşre Haz.) Nazif ÖZTÜRK. Vakıflar Dergisi, (18), 43-59.

İnalcık, H. \& Seyitdanlıoğlu, M. (2017). (Ed.), Tanzimat: değişim sürecinde Osmanlı imparatorluğu. (6. Baskı). İstanbul: Türkiye İş Bankası Kültür. İskit, S. (1943). Türkiye'de matbuat idareleri ve politikaları. Ankara: Başvekâlet Basın ve Yayın Umum Müdürlüğü.

İstanbul Üniversitesi Kütüphane ve Dokümantasyon Daire Başkanlığı Nadir Eserler Kütüphanesi. Vükelâ ve rical-i devletten bazılarının resimleri: Kemal Paşa. II. Abdülhamid Han Fotoğraf Albümleri. Yer ve Demirbaş numarası: NEKYA90622/11A, http://nek.istanbul.edu.tr:4444/ekos/FOTOGRAF/90625---0009.jpg (16.05.2020). 
İstanbul Üniversitesi Kütüphane ve Dokümantasyon Daire Başkanlığı Nadir Eserler Kütüphanesi. Vükelâ ve rical-i devletten bazılarının resimleri: Kemal Paşa. II. Abdülhamid Han Fotoğraf Albümleri, Yer ve Demirbaş numarası: NEKYA90625/1, http://nek.istanbul.edu.tr:4444/ekos/FOTOGRAF/90625---0001.jpg (16.05.2020).

Kaplan, M. (1994). Mustafa Reşid Paşa ve yeni aydın tipi. Mustafa Reşid Paşa ve Dönemi Semineri: Bildiriler, Ankara 13-14 Mart 1985. (2. Baskı). Ankara: Atatürk Kültür, Dil ve Tarih Yüksek Kurumu Türk Tarih Kurumu.

Kara Pilehvarian, N. (2001). Bezmialem Valide Sultan'ın eğitim ıslahatlarındaki rolü ve Valide Mektebi/Dârûlmaarif. (Der.) Hidayet Yavuz Nuhoğlu, Osmanlı Dünyasında Bilim ve Eğitim Milletlerarası Kongresi Tebliğleri. İstanbul: İslam Tarih, Sanat ve Kültür Araştırma Merkezi.

Kara, I. \& Birinci, A. (2012). Bir eğitim tasavvuru olarak mahalle/sıbyan mektepleri: Hatıralar, yorumlar, tetkikler. (2. Baskı) İstanbul: Dergâh.

Kaya Doğanay, F. (2011). Tanzimat'tan Cumhuriyet'e rüştiye mektepleri. Yayımlanmamış Doktora Tezi. Atatürk Üniversitesi Sosyal Bilimler Enstitüsü, Erzurum.

Kayaoğlu, T. (1996). Türkiye’de tercüme müesseseleri. Yayımlanmamış Yüksek Lisans Tezi. İstanbul Üniversitesi Sosyal Bilimler Enstitüsü, İstanbul. Koçer, H. A. (1991). Türkiye'de modern eğitimin doğuşu ve gelişimi (1773-1923). (2. Baskı). İstanbul: Milli Eğitim Bakanlı̆̆ı.

Küçükler, O. Z. (2014). Encümen-i Daniş. Yayımlanmamış Doktora Tezi. Ankara Üniversitesi Sosyal Bilimler Enstitüsü, Ankara.

Maarif Salnamesi (Salname-i Nezaret-i Maarif-i Umumiyye), (H. 1316/M. 1898-1899). (Birinci Def'a Olarak Tertib Edilmiştir), Darülhilafetülâliye/istanbul: Matbaa-i Amire.

Maarif Salnamesi (Salname-i Nezareti Maarif-i Umumiyye), (H. 1321/M. 1903-1904). Altıncı Def'a Olarak Tertib Edilmiştir, Darülhilafetülâliye/İstanbul: Matbaa-i Amire.

Mahmud Cevad, i. N. (2002). Maarif-i Umumiye Nezareti tarihçe-i teşkilât ve icraâtı. (Yay. Haz.) Mustafa Ergün, Tayip Duman, Sebahattin Arıbaş, H. Hüseyin Dilaver. Ankara: Millî Eğitim Basımevi.

Mehmed Atıf, (2016). Hatıra-i Atıf. (Haz.) Nurettin Gemici ve Hikmet Toker. İstanbul: TBMM Milli Saraylar.

Pakalın, M. Z. (1940). Son sadrazamlar ve başvekiller. (Cilt 1-6). İstanbul: Ahmet Sait Matbaası.

Pakalın, M. Z. (1993). Osmanlı deyimleri sözlüğü. İstanbul: Milli Eğitim Basımevi.

Sakaoğlu, N. (1994). Valide Mektebi. Dünden Bugüne istanbul Ansiklopedisi. (Cilt 7), 363-364. İstanbul: Türkiye Ekonomik ve Toplumsal Tarih Vakfı (Kültür Bakanlığı ortaklığıyla).

Strauss, A. \& Corbin, J. (1998). Basics of Qualitative Research Techniques. Thousand Oaks, CA: Sage Publications.

Somel, S. A. (2015). Osmanlı'da eğitimin modernleşmesi (1839-1908): İslâmlaşma, otokrasi ve disiplin. (2. Baskı). (Çev.) Osman Yener. İstanbul: İletişim.

Şahbaz, N. K. (2005). Tanzimat'tan Cumhuriyet'in ilk yıllarına kadar (1839-1928) Türkiye'de ilkokuma ve yazma öğretimi. Yayımlanmamış Doktora Tezi. Gazi Üniversitesi Eğitim Bilimleri Enstitüsü, Ankara.

T.C. Başbakanlık Devlet Arşivleri Genel Müdürlüğü, (1992), Osmanlı belgelerinde Bosna-Hersek. Ankara: Osmanlı Arşivi Daire Başkanlığı.

Takvim-i Vekayi, no: 372, (H. 23 Rebiülahir 1264/M. 29 Mart 1848); no: 361; no: 425, (H. 23 Cemaziyelahir 1266/M. 6 Mayıs 1850); no: 504, (H. 3 Haziran 1283/M. 15 Haziran 1867).

The Dundee Courier And Argus, (Wednesday 30 May 1866 / Çarşamba 30 Mayıs 1866), No: 3998.

The Newcastle Journal, (Saturday 28 May 1853 / Cumartesi 28 Mayıs 1853), Vol. XXII, No: 1103.

Türkiye Büyük Millet Meclisi (TBMM), (1997). Türk parlamento tarihi l. ve II. Meşrutiyet, (Cilt II), Ankara: TBMM Vakfı.

Türkgeldi, A. F. (2013). Maruf Simalar. Haz. S. A. Somel \& M. Kalpaklı. Ankara: Atatürk Kültür, Dil ve Tarih Yüksek Kurumu TTK.

Unat, F. R. (1964). Türkiye eğitim sisteminin gelişmesine tarihi bir bakış. Ankara: Milli Eğitim Basımevi.

Ünal, U. \& Birbudak, T. S. (2013). İstanbul Dârulmuallimîni (1848-1924). Ankara: Atatürk Kültür, Dil ve Tarih Yüksek Kurumu Atatürk Araştırma Merkezi.

Yıldırım, M. A. (2010). Tanzimat döneminde meslek okulları. Yayımlanmamış Doktora Tezi. Ankara Üniversitesi Sosyal Bilimler Enstitüsü, Ankara.

Yıldırım, M. A. (2012). Tanzimat döneminde Darülmuallimîn mezunlarının rüşdiyelere tayini. Musa Çadırcı'ya Armağan Yazılar, Ankara: Bilgin Kültür Sanat. 


\section{EKLER}

\section{Ek 1 Ahmed Kemal Paşa'nın Fotoğrafı*}

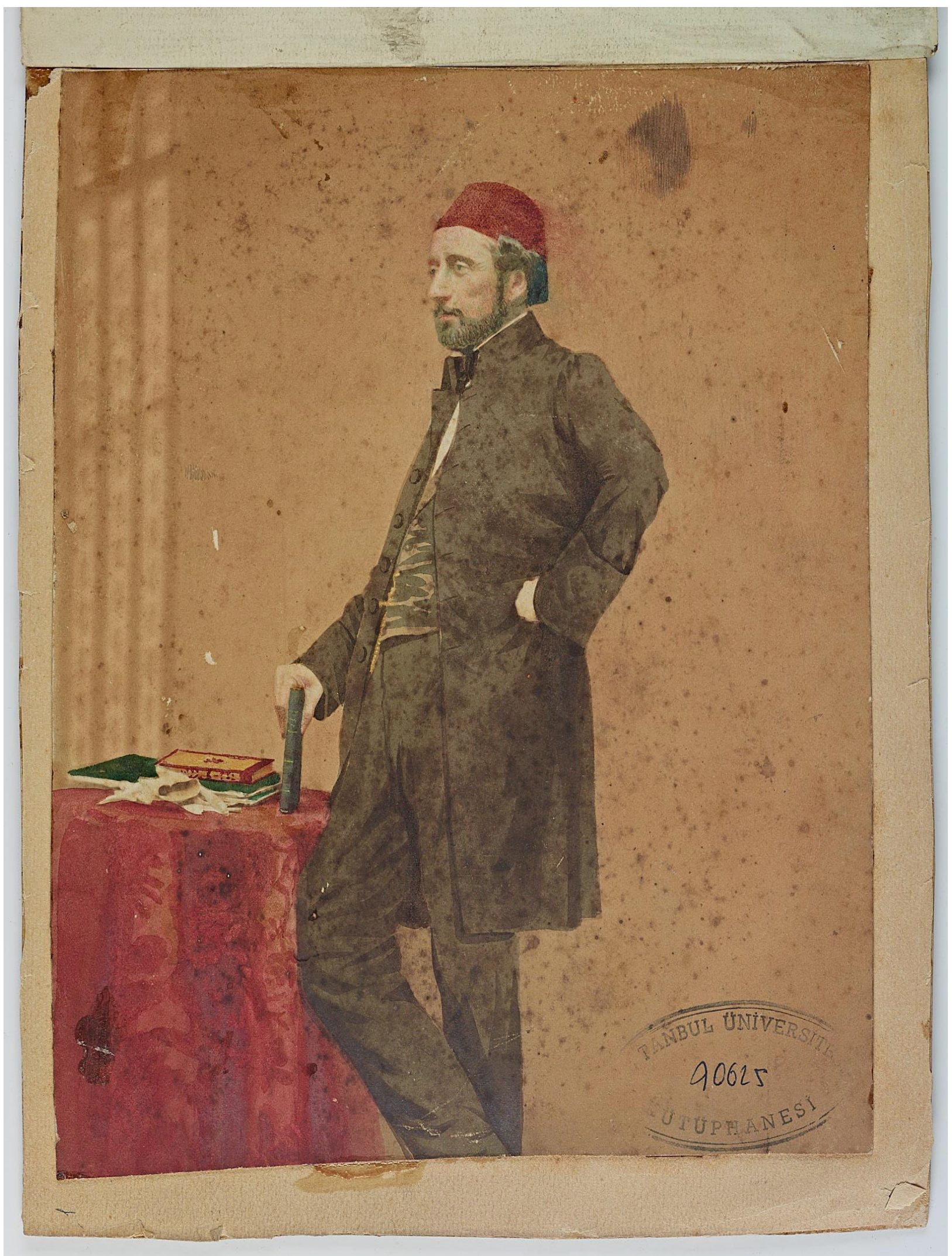

* İstanbul Üniversitesi Kütüphane ve Dokümantasyon Daire Başkanlığı Nadir Eserler Kütüphanesi. Vükelâ ve rical-i devletten bazılarının resimleri: Kemal Pașa. Il. Abdülhamid Han Fotoğraf Albümleri, Yer ve Demirbaș numarası: NEKYA90625/1. 


\section{Ek 2 Ahmed Kemal Paşa'nın Fotoğrafı*}

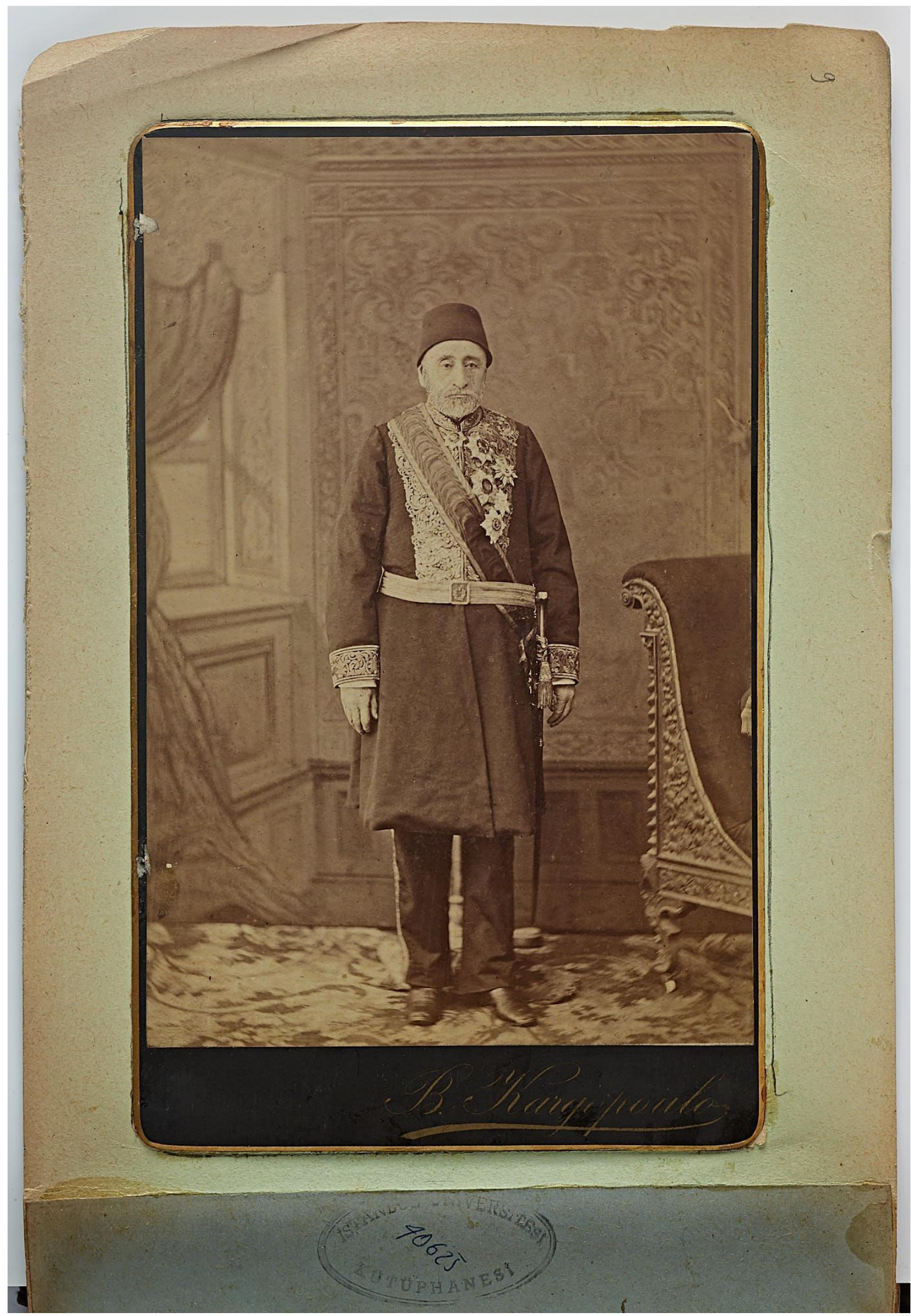

\footnotetext{
* İstanbul Üniversitesi Kütüphane ve Dokümantasyon Daire Başkanlığı Nadir Eserler Kütüphanesi. Vükelâ ve rical-i devletten bazılarının resimleri: Kemal Pașa. Il. Abdülhamid Han Fotoğraf Albümleri, Yer ve Demirbaş numarası: NEKYA90622/11A.
} 